\title{
Chapter 27 \\ Assessment of Nutrient Trading Services from Bivalve Farming
}

\author{
J. G. Ferreira and S. B. Bricker
}

\begin{abstract}
This review examines key aspects of bivalve services, with a dual emphasis on commercial production and eutrophication control, and explores how the two can be combined by means of market instruments. Our focus is on regulatory trading services, in particular on ways in which nutrient credits can be traded for improved water quality management and better food security. We provide budgets for nutrient loading in Europe, North America, and China, factoring in point and non-point loading, and assess the contribution of finfish aquaculture. We then review the role of commercially cultivated bivalves for the same geographic areas, to assess the scope of combining farmed bivalves and top-down control of symptoms of nutrient enrichment. Water quality trading has existed as a concept for the past 40 years, but it can claim few success stories; we examine some of the challenges and potential solutions, as well as practical implementations, with a focus on nonpoint trading, for mitigation of diffuse nutrient loading. Finally, we discuss options for different indicators, and provide examples of how an assessment can be made, including the valuation of regulatory services provided by commercially grown bivalves. We conclude that the role of bivalves in nutrient credit trading programmes should form an integral part of ecosystem-based management. From the perspective of aquaculture enhancement, which is fundamental for improved food security, this is a triple-win, providing competitiveness of agriculture, eco-intensification of aquaculture, and greater consumer safety.
\end{abstract}

Abstract in Chinese 摘要: 本文综述了双壳贝类服务价值的主要方面, 重点强 调了贝类在商业化生产和富营养化控制方面的作用, 并探讨了如何通过市场 手段将两者结合起来。我们的关注点在于调节类的配额贸易服务, 特别是如 何利用 “营养盐排放配额” 的方式来促进水质改善管理和粮食安全保障。我 们举例说明欧洲, 北美和中国一些水域的营养负荷收支情况, 分别从点源以及

J. G. Ferreira $(\triangle)$

DCEA, FCT, New University of Lisbon, Monte de Caparica, Portugal

e-mail: joao@hoomi.com

S. B. Bricker

NOAA - National Ocean Service, NCCOS, Silver Spring, MD, USA

e-mail: Suzanne.Bricker@noaa.gov 
非点源输入两方面评估了鱼类养殖的贡献份额。然后, 我们总结分析了在相 同地理区域开展商业化双壳贝类养殖对富营养化的下行控制作用。水质配额 贸易的概念已经存在四十多年, 但目前并没有什么成功的运用案例。本文研 讨了水质配额贸易推行存在的一些挑战和潜在的解决方案, 并且着重以非点 源输入配额贸易为例探讨了减轻扩散性营养物输入的实施方案。最后, 我们 对评估指标的的选择进行了讨论, 并提供了一些评估实例, 包括对商业规模双 壳贝类养殖的生态调节功能的评估。双壳贝类在 “营养盐配额贸易” 项目中 的作用应该被视为生态系统管理的一部分。从加强水产养殖的角度考量, 这 对改善粮食安全可起到根本作用, 因此可以三赢：一是提高了农业竞争力, 二是有助于实现水产养殖生态集约化，三是更进一步的保障消费者需求。

Keywords Bivalves $\cdot$ Eutrophication $\cdot$ Regulatory services $\cdot$ Nutrient credit trading $\cdot$ Trading mechanisms $\cdot$ Indicators and assessment

关键词 双壳贝类 ・ 富营养化 ・ 调节服务 - “营养盐配额贸易” ・贸 易机制 ・ 指标和评估

\subsection{Introduction and Scope}

Nutrient discharge to coastal waters is a major driver in the development of eutrophication symptoms (Bricker et al. 2003; Borja et al. 2008; Diaz and Rosenberg 2008). The conceptual relationship for these primary and secondary symptoms, also called direct and indirect effects (OSPAR 2010), is illustrated in Fig. 27.1.

Eutrophication has been defined in several different ways (e.g. Anonymous 1991a, b; Nixon 1995; Cloern 2001; Andersen et al. 2006); for this review, we have adopted the European Union (EU) Marine Strategy Framework Directive (MSFD, 2008/56/EC) definition, since our emphasis is on the trading potential of nutrient abatement services. The MSFD defines eutrophication (Ferreira et al. 2011) as 'a process driven by enrichment of water by nutrients, especially compounds of nitrogen and/or phosphorus, leading to: increased growth, primary production and biomass of algae; changes in the balance of organisms, and water quality degradation. The consequences of eutrophication are undesirable if they appreciably degrade ecosystem health and/or the sustainable provision of goods and services.'

Nutrient pressures on estuarine and marine areas have intensified in many parts of the world as populations are increasingly drawn to coastal zones. Nevertheless, efforts to control loading have been mostly successful in the reduction of pointsource discharges, particularly in the Western world, but diffuse inputs from agriculture are far less easy to reduce (e.g. Gunningham and Sinclair 2005; Collins and McGonigle 2008).

In the West, some agricultural outputs (diffuse sources) are used as fertilizer for land-based crops; in other parts of the world, particularly Asia, where nutrient sup- 

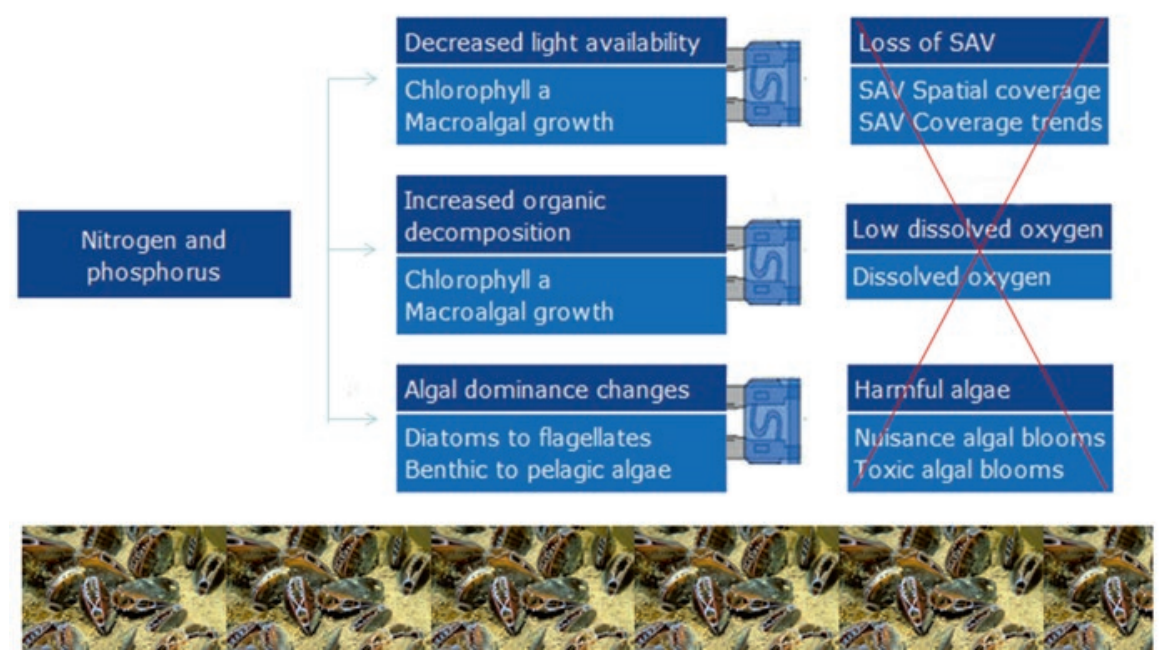

Fig. 27.1 General conceptual scheme of eutrophication, including top-down control by filterfeeding bivalves. The boxes for primary and secondary symptoms (identical to direct and indirect effects), show the symptom name (e.g. Decreased light availability), and below it the indicators for assessment. Bivalves act as a circuit-breaker (marked S), interrupting the organic decomposition cycle (secondary symptoms), which are thus (as a group) marked with an X (SAV Submerged Aquatic Vegetation, normally considered to mean seagrasses rather than macroalgae)

ply is a key limiting factor for food production, re-use takes place both on land and in water. In the latter case, nutrients may be taken up directly in inorganic extractive aquaculture, e.g. for seaweeds such as Nori (Porphyra yezoensis), and other plants such as water spinach (Ipomoea aquatica), but also indirectly through organic extraction.

The indirect re-use of dissolved nitrogen and phosphorus, after conversion into particulate organic forms through primary production, is a key step in the removal of these compounds from coastal ecosystems; this is largely mediated by filterfeeding bivalves (Gerritsen et al. 1994; Higgins et al. 2011; Petersen et al. 2014; Ferreira and Bricker 2016).

The world's annual aquaculture production in 2014 was estimated to be $73.8 \times 10^{6}$ tonnes (FAO 2016), of which 50\% corresponds to non-fed, i.e. extractive, aquaculture. World bivalve production for 2014 was $16 \times 10^{6}$ tonnes (FAO 2016), of which $1.7 \%$ takes place inland (all in Asia). Overall, bivalve aquaculture accounts for $21.6 \%$ of the total production, or about two-fifths of total extractive aquaculture.

Farmed bivalve production shows a strong regional imbalance: Asia grows 94.2\% of all molluscs, while the Americas and Europe account for 1.6 and $4.2 \%$ respectively. In Europe, practically all production takes place in the European Union, where bivalves account for $44 \%$ of total aquaculture (Ferreira and Bricker 
2015; European Commission 2016). The inclusion of Norway brings this figure down to $20 \%$, which is more in line with the world average (Ferreira and Bricker 2015).

Thirty-five years ago, two seminal papers (Cloern 1982; Officer et al. 1982) described the role of benthic filter-feeders in top-down control of eutrophicationboth authors cite Mann and Ryther (1977), who discussed extractive organic aquaculture. Together, these publications are at the core of subsequent work on nutrient-related bivalve ecosystem services (e.g. Lindahl et al. 2005; Xiao et al. 2007; Kellogg et al. 2014; Saurel et al. 2014; Rose et al. 2015). In recent years, this has gained attention as a promising nutrient management practice to complement traditional land-based measures (Rose et al. 2014, 2015; Petersen et al. 2014).

As integrated coastal zone management (ICZM) evolved, and legislative instruments (e.g. the EU Water Framework Directive: WFD, 2000/60/EC), and policy guidance documents (e.g. USEPA 2008a) became available, options for nutrient abatement were reviewed in detail. In particular, cost-benefit (Nunneri et al. 2007) and cost-effectiveness (Gren et al. 2008; Lancelot et al. 2011) analysis was used as a tool, and the potential role of nutrient credit trading was considered, especially on the eastern seaboard of the United States (Virginia DEQ 2008; CT-DEP 2010).

Despite clear evidence that filter-feeding bivalves play an important role in nutrient management, or more specifically in management of nutrient-related issues (e.g. water clarity), policy-makers have been slow to embrace the fact that top-down eutrophication control mechanisms associated with commercial bivalve farming should be part of any integrated watershed-level management strategy. ${ }^{1}$

In this review, we examine (i) nutrient loading and the role of commercially cultivated bivalves; (ii) nutrient credit trading mechanisms and indicator selection; and (iii) potential assessment methodologies and their application.

\subsection{Nutrient Loading and the Role of Cultivated Bivalves}

An assessment of the potential role of filter-feeding bivalves in offsetting eutrophication symptoms requires an evaluation of the magnitude of both the inputs and outputs, i.e. land-based nutrient loading (to which nutrient emissions from finfish cage culture could be added), and bivalve production and nitrogen removal. Management emphasis is typically placed on nitrogen rather than phosphorus, since the former is considered to be the limiting nutrient for primary production in estuarine and coastal systems (Ryther and Dunstan 1971; Boynton et al. 1982; Nixon and

\footnotetext{
${ }^{1}$ Virginia is an exception: House Bill $\mathrm{N}^{\circ} 176$ (2012) includes in Article 1.B.1: ‘...incineration or management of manures, land use conversion, stream or wetlands restoration, bivalve aquaculture, algal harvesting, and other established or innovative methods of nutrient control or removal.' More recently the Chesapeake Bay Partnership has approved the use of harvested oyster tissue as a nutrient best management practice (BMP) whereby MD and VA jurisdictions are allowed to use nutrient credits from oyster tissue to count toward fulfilment of nutrient reduction goals (Oyster BMP Expert Panel 2016).
} 
Pilson 1983; NRC 1993). It is worth noting, however, that this is not universally accepted (see Howarth 1988, for a review).

From the standpoint of land-based emissions control, the distinction is probably irrelevant, since wastewater treatment facilities (WWTF) remove both nitrogen and phosphorus (USEPA 2004a), and fertilizer reduction measures for agriculture do likewise. From the perspective of top-down control by bivalves, this is probably also a moot point, because filter-feeders remove both elements. Where the question may become relevant is in the valuation of a specific nutrient, but this can be overcome either by (i) using population-equivalent (PEQ) coefficients for both $\mathrm{N}$ and $\mathrm{P}$ (e.g. Ferreira et al. 2007a), thereby dealing with avoided costs; or (ii) using an indicator associated with the reduction of symptoms rather than causative factors (see section on indicator suitability).

Recent work in the United States (Oyster BMP Expert Panel 2016) already takes both nitrogen and phosphorus into account when considering regulatory services from bivalve aquaculture.

\subsubsection{Nutrient Loading to the Coastal Zone}

The nutrient loading and eutrophication status of some European waters were reviewed in Ferreira and Bricker (2016); source-apportionment of nutrient loads is key for policy decisions, but in many regions this is not fully available. In this review, we have expanded and improved the European data set (see Table 2 in Ferreira and Bricker 2016) to include loading data for major parts of the world's coastal ocean (Table 27.1); where possible, we have discriminated the nutrient sources by combining data from various authors, including: (i) Ærtebjerg et al. (2001) for Europe; (ii) NRC (2000), and Wise and Johnson (2011) for North America; and (iii) Tong et al. (2015) and the China Fishery Statistical Yearbook (2016) for China.

Where point-source and diffuse inputs can be assessed separately, the latter are typically $70-80 \%$ of the total loading. This is reflected in the ratio between calculated population-equivalents (PEQ) for load estimates and population data. These ratios are 1.7 for Europe, 3.3 for the US, and 6.4 for Canada. The ratio for China is below one, which suggests that a significant component of the total load to the coastal area is not included-coastal diffuse source loads per unit area tend to be higher than those from major rivers, since intensive agriculture is often concentrated close to the coast, and smaller rivers draining these areas would have a higher load than major rivers that also drain inland areas with natural land uses (Nunes, pers. com.)

China's freshwater finfish aquaculture $\left(27.2 \times 10^{6} \mathrm{t}\right.$ in 2015 , China Fishery Statistical Yearbook 2016) far exceeds that of marine finfish (Table 27.1); carp (grass, silver, and bighead) account for about half the freshwater production, but, although the last two are planktivores, and also feed on particulate organic detritus, their role in reducing loading is questionable, because they are mainly cultivated 
Table 27.1 Nitrogen and phosphorus loading to marine waters $\left(10^{3}\right.$ tonnes, percent total in parentheses where applicable) for major areas of the world

\begin{tabular}{|c|c|c|c|c|}
\hline & $\begin{array}{l}\text { Total } \\
\text { nitrogen }\end{array}$ & $\begin{array}{l}\text { Total } \\
\text { phosphorus }\end{array}$ & $\begin{array}{l}\text { Redfield } \\
\text { ratio }\end{array}$ & Notes \\
\hline \multicolumn{5}{|l|}{$\underline{\text { Europe }}$} \\
\hline Norwegian Sea ${ }^{\mathrm{a}}$ & $28.4(30.7)$ & 1.5 & 18.9 & \\
\hline Barents Sea $^{\mathrm{a}}$ & $5.4(5.8)$ & 0.3 & 18.0 & \\
\hline$\underline{\text { Sub-total direct loading }}$ & $33.8(36.6)$ & 1.8 & 18.8 & \\
\hline $\begin{array}{l}\text { Finfish aquaculture } \\
\text { (Norway) }{ }^{b, c}\end{array}$ & $55.9(60.5)$ & 14.5 & 3.9 & \\
\hline $\begin{array}{l}\text { Finfish aquaculture (Faroe } \\
\text { Islands) }{ }^{d, e}\end{array}$ & $2.7(2.9)$ & 0.7 & 3.9 & \\
\hline 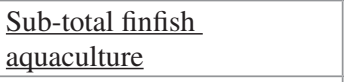 & $58.6(63.4)$ & 15.2 & 3.9 & \\
\hline$\underline{\text { Sub-total Arctic waters }}$ & 92.4 & 17.0 & 5.4 & \\
\hline \multicolumn{5}{|l|}{ Baltic Sea ${ }^{\mathrm{f}}$} \\
\hline Point sources & $243.0(29.0)$ & 12.0 & 20.2 & $\begin{array}{l}\text { EEA ratio but } 2010 \\
\text { HELCOM figure }\end{array}$ \\
\hline Diffuse sources & $592.0(70.7)$ & 29.3 & 20.2 & $\begin{array}{l}\text { EEA ratio but } 2010 \\
\text { HELCOM figure }\end{array}$ \\
\hline Finfish aquaculture ${ }^{b}$ & $2.5(0.3)$ & 0.6 & 3.9 & $\begin{array}{l}\text { N/P ratios calculated for } \\
\text { salmon }\end{array}$ \\
\hline Sub-total Baltic Sea & 837.5 & 42.0 & 20.0 & \\
\hline \multicolumn{5}{|l|}{$\begin{array}{l}\text { North Sea, Celtic Sea, Bay } \\
\text { of Biscay }\end{array}$} \\
\hline Point sources & $368.0(30.5)$ & 24.0 & 15.4 & $\begin{array}{l}\text { EEA ratio but } 2010 \\
\text { OSPAR data }\end{array}$ \\
\hline Diffuse sources & $837.0(69.4)$ & 54.5 & 15.4 & $\begin{array}{l}\text { EEA ratio but } 2010 \\
\text { OSPAR data }\end{array}$ \\
\hline Finfish aquaculture & $0.3(<0.1)$ & 0.1 & 3.9 & \\
\hline $\begin{array}{l}\text { Sub-total North Sea, Celtic } \\
\text { Sea, Biscay }\end{array}$ & 1205.3 & 78.5 & 15.3 & \\
\hline \multicolumn{5}{|l|}{ Mediterranean Sea a } \\
\hline $\begin{array}{l}\text { Nutrient hotspots } \\
\text { (S. Europe and N. Africa) }\end{array}$ & $259.7(12.9)$ & 75.2 & 3.5 & \\
\hline Potential diffuse sources & $\begin{array}{l}1747.7 \\
(87.1)\end{array}$ & 126.7 & 13.8 & $\begin{array}{l}\text { Estimated: } \\
\text { Total-hotspots- } \\
\text { aquaculture }\end{array}$ \\
\hline $\begin{array}{l}\text { Finfish aquaculture } \\
\text { (gilthead bream) }^{\mathrm{b}}\end{array}$ & $4.3(0.2)$ & 1.1 & 3.9 & \\
\hline $\begin{array}{l}\text { Finfish aquaculture } \\
\text { (European seabass) }^{\mathrm{b}}\end{array}$ & $3.1(0.2)$ & 0.8 & 3.9 & \\
\hline $\begin{array}{l}\underline{\text { Sub-total finfish }} \\
\text { aquaculture }\end{array}$ & $7.4(0.4)$ & 1.9 & 3.9 & \\
\hline $\begin{array}{l}\text { Sub-total Mediterranean } \\
\text { Sea }\end{array}$ & 2007.4 & 201.9 & 9.9 & $\begin{array}{l}\text { Includes N. African } \\
\text { discharge to Med }\end{array}$ \\
\hline
\end{tabular}

(continued) 
Table 27.1 (continued)

\begin{tabular}{|c|c|c|c|c|}
\hline & $\begin{array}{l}\text { Total } \\
\text { nitrogen }\end{array}$ & $\begin{array}{l}\text { Total } \\
\text { phosphorus }\end{array}$ & $\begin{array}{l}\text { Redfield } \\
\text { ratio }\end{array}$ & Notes \\
\hline Total Europe & 4142.6 & 339.4 & & $\begin{array}{l}1255 \text { million } \mathrm{PEQ}^{\mathrm{h}} \text {; tot. } \\
\text { pop. } 726 \text { million }\end{array}$ \\
\hline United States & & & & NRC (2000) \\
\hline \multicolumn{5}{|l|}{$N E$ coast ${ }^{\dagger}$} \\
\hline Rivers and estuaries & $270.0(40.3)$ & 17.6 & 15.4 & \\
\hline Atmospheric & $210.0(31.3)$ & 13.7 & & \\
\hline \multicolumn{5}{|l|}{$S E$ coast ${ }^{\mathrm{j}}$} \\
\hline Rivers and estuaries & $130.0(19.4)$ & 8.5 & 15.4 & \\
\hline Atmospheric & $60.0(9.0)$ & 3.9 & & \\
\hline$\underline{\text { Sub-total US east coast }}$ & 670.0 & 43.6 & & \\
\hline \multicolumn{5}{|l|}{ Gulf of Mexico $^{\mathrm{j}}$} \\
\hline Rivers and estuaries & $\begin{array}{l}2100.0 \\
(88.2)\end{array}$ & 136.8 & 15.4 & \\
\hline Atmospheric & $280.0(11.8)$ & 18.2 & & \\
\hline 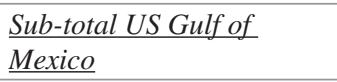 & 2380.0 & 155.0 & & \\
\hline \multicolumn{5}{|l|}{ Pacific Northwest ${ }^{\mathrm{k}}$} \\
\hline Point sources & $100.9(21.8)$ & 6.6 & 15.4 & \\
\hline Diffuse sources & $362.2(78.2)$ & 23.6 & 15.4 & \\
\hline Sub-total US Pacific NW & 463.2 & 30.2 & & $\begin{array}{l}1 \% \text { load from } \\
\text { watersheds in Western } \\
\text { Canada }\end{array}$ \\
\hline Marine finfish aquaculture ${ }^{1}$ & 0.9 & 0.2 & 3.9 & $\approx 0 \%$ total loading \\
\hline Total United States & 3514 & 229 & & $\begin{array}{l}1065 \text { million } \mathrm{PEQ}^{\mathrm{h}} \text {; tot. } \\
\text { pop. } 319 \text { million }\end{array}$ \\
\hline
\end{tabular}

\section{Canada}

\begin{tabular}{|c|c|c|c|c|}
\hline \multicolumn{5}{|l|}{$N E$ Canada $^{\mathrm{j}}$} \\
\hline Rivers and estuaries & $160.0(21.9)$ & 10.4 & 15.4 & \\
\hline Atmospheric & $100.0(13.7)$ & 6.5 & & \\
\hline \multicolumn{5}{|l|}{ St. Lawrence watershed } \\
\hline Rivers and estuaries & $340.0(46.6)$ & 22.1 & 15.4 & \\
\hline Atmospheric & $130.0(17.8)$ & 8.5 & & \\
\hline Finfish aquaculture ${ }^{\mathrm{c}, \mathrm{m}}$ & $1.2(0.2)$ & 0.3 & 3.9 & \\
\hline $\begin{array}{l}\text { Sub-total Canadian east } \\
\text { coast }\end{array}$ & 731.2 & 47.8 & & \\
\hline \multicolumn{5}{|l|}{ Western Canada } \\
\hline Finfish aquaculture ${ }^{\mathrm{c}, \mathrm{m}}$ & 2.2 & 0.6 & 3.9 & \\
\hline $\begin{array}{l}\text { Sub-total Canadian west } \\
\text { coast }\end{array}$ & - & - & & $\begin{array}{l}4000 t^{\text {year }}{ }^{-1} \text { into US } \\
\text { west coast from Canada }\end{array}$ \\
\hline Total Canada & 733.3 & 48.4 & & $\begin{array}{l}222 \text { million } \mathrm{PEQ}^{\mathrm{h}} \text {; tot. } \\
\text { Pop. } 35 \text { million }\end{array}$ \\
\hline
\end{tabular}


Table 27.1 (continued)

\begin{tabular}{|c|c|c|c|c|}
\hline & $\begin{array}{l}\text { Total } \\
\text { nitrogen }\end{array}$ & $\begin{array}{l}\text { Total } \\
\text { phosphorus }\end{array}$ & $\begin{array}{l}\text { Redfield } \\
\text { ratio }\end{array}$ & Notes \\
\hline \multicolumn{5}{|l|}{ China } \\
\hline \multicolumn{5}{|l|}{ Major rivers ${ }^{\mathrm{n}}$} \\
\hline Yangtze & $\begin{array}{l}1690.0 \\
(62.5)\end{array}$ & 168.0 & 10.1 & \\
\hline Huanghe & $16.5(0.6)$ & 0.8 & 20.5 & \\
\hline Liaohe & $3.8(0.1)$ & 0.3 & 11.1 & \\
\hline Haihe & $4.4(0.2)$ & 0.2 & 22.4 & \\
\hline Huaihe & $38.2(1.4)$ & 2.6 & 14.6 & \\
\hline Qiantangjiang & $47.3(1.7)$ & 1.7 & 28.2 & \\
\hline Minjiang & $87.0(3.2)$ & 3.2 & 27.4 & \\
\hline Zhujiang & $785.9(29.0)$ & 30.6 & 25.7 & \\
\hline Sub-total river loading & $\begin{array}{l}2673.2 \\
(98.8)\end{array}$ & 207.5 & 12.9 & \\
\hline $\begin{array}{l}\text { Coastal finfish aquaculture } \\
\text { o,p }\end{array}$ & $32.8(1.2)$ & 8.5 & 3.9 & \\
\hline Total China & 2706.0 & 215.9 & & $\begin{array}{l}820 \text { million } \mathrm{PEQ}^{\mathrm{h}} \text {; total } \\
\text { pop of } 1.4 \text { billion }\end{array}$ \\
\hline $\begin{array}{l}\text { Total Europe, North } \\
\text { America, and China }\end{array}$ & 11095.9 & 832.8 & & 3.36 billion $\mathrm{PEQ}^{\mathrm{h}, \mathrm{q}}$ \\
\hline
\end{tabular}

${ }^{\mathrm{a}}$ Ertebjerg et al. (2001)

${ }^{\mathrm{b}}$ Ferreira and Bricker (2016)

${ }^{c}$ Feed and faeces N/P ratios from Wang et al. (2013); N/P ratios for excretory products from Wang et al. (2014)

dProduction data: http://www.salmon-from-the-faroe-islands.com/

${ }^{e}$ Weight conversion coefficients recalculated from Acharya (2011)

fHELCOM (2010)

'OSPAR (2010)

${ }^{\text {h}} 1 \mathrm{PEQ}=3.3 \mathrm{~kg} \mathrm{~N}$ ind $^{-1}$ year $^{-1}$ (Ferreira and Bricker 2016)

${ }^{\text {i}}$ Population: $508 \times 10^{6}$ for EU; $118 \times 10^{6}$ for other European countries; $100 \times 10^{6}$ for North African Maghreb

${ }^{\mathrm{j} N R C}(2000)$

${ }^{\mathrm{k}}$ Wise and Johnson (2011)

'Data for 2012, FAO FishStatJ; http://www.fao.org/fishery/statistics/software/fishstatj/en

${ }^{\mathrm{m}}$ Canadian Department of Fisheries and Oceans (DFO), 2016; reported live weight production of 30,266 t year ${ }^{-1}$ (East Coast) and 56,276 t year ${ }^{-1}$ (West Coast) http://www.dfo-mpo.gc.ca/stats/ aqua/aqua14-eng.htm

"Tong et al. (2015)

${ }^{\circ}$ Marine finfish live weight production $=1.31 \times 10^{6} \mathrm{t} \mathrm{year}^{-1}($ China Fishery Statistical Yearbook 2016) as compared to $27.15 \times 10^{6}$ t year $^{-1}$ in freshwater (China Fishery Statistical Yearbook 2016) ${ }^{\mathrm{p} L o a d i n g}$ calculated using data from Ferreira and Bricker (2016), assuming a cultivation period of 500 days and $0.5 \mathrm{~kg}$ biomass per fish

${ }^{q}$ Calculations were based on a PEQ equivalent for treated domestic effluent. If a coefficient of $4.4 \mathrm{~kg} \mathrm{~N} \mathrm{PEQ}^{-1}$ year $^{-1}$ (untreated effluent) is used, the equivalent population is reduced to 2.52 billion (all PEQ values will be lower by $25 \%$ ) 
with grass carp, and re-use waste feed and other side-streams of fed aquaculture. Equally, it is unclear how much nitrogen and phosphorus these 27 million tonnes of farmed fish might add to the overall load, because of the practice of carp polyculture, where organically extractive species offset pellet-fed ones, and because of the widespread use of Integrated Multi-Trophic Aquaculture (IMTA).

Table 27.1 also includes loading from (marine) finfish aquaculture for Europe, USA, Canada, and China, which together account for $1 \%$ of the overall nitrogen discharge (3.3\% of the phosphorus, because of lower N:P ratios in finfish emissions). Arctic waters are the only area where the proportion of $\mathrm{N}$ load due to finfish is significant $(63.4 \%$, mainly due to Norwegian salmon and trout production), but the total contribution of this region to the European ${ }^{2}$ budget is only $2 \%$.

For all the areas considered, with the possible exception of Canada, eutrophication has been identified as an issue (see e.g. for Europe: HELCOM 2009, 2014; OSPAR 2010; Ferreira and Bricker 2016; US: Howarth et al. 2002; Bricker et al. 2008; China: Xiao et al. 2007; SOA 2016). In the US, a large part of the NE seaboard and Gulf of Mexico are impacted (Bricker et al. 2008), and in China, $9.8 \times 10^{4} \mathrm{~km}^{2}$ were affected in 2012 (Tong et al. 2015). Secondary symptoms of eutrophication (sensu Bricker et al. 2003) such as hypoxia and nuisance and toxic blooms (HAB) typically occur as a consequence of excessive primary productionin China, 73 offshore HAB events were reported in 2012, affecting an area of almost $8000 \mathrm{~km}^{2}$ (Tong et al. 2015). Eutrophication-related hypoxia has been documented in Europe (Diaz and Rosenberg 2008), the US (Bricker et al. 2008), and China (Tong et al. 2015), leading in extreme cases to the development of 'dead zones' (e.g. Rabalais et al. 2002).

Cultivation of bivalve species is spatially ubiquitous in the parts of the world covered in Table 27.1, although the stocking density varies widely, as do the main species farmed. All this production shares a common ecosystem service by exerting top-down control on primary symptoms of eutrophication, and acts as a circuitbreaker in the eutrophication cycle (Ferreira and Bricker 2016), as illustrated in Fig. 27.1.

\subsubsection{Bivalve Production}

A detailed breakdown of national bivalve production for Europe is given in Ferreira and Bricker (2015). The global European production is shown in Fig. 27.2, with the bivalve bivalve producing nations highlighted.

The production analysis for Europe has been extended herein to match the nutrient loading data shown in Table 27.1: total numbers for Europe, the United States, Canada, and China are given in Table 27.2. In total, almost $13 \times 10^{6} \mathrm{t} \mathrm{year}^{-1}$ are produced in the areas considered, about $79 \%$ of the estimated world production

\footnotetext{
${ }^{2}$ Includes North African Maghreb for estimates of loading to the Mediterranean Sea.
} 


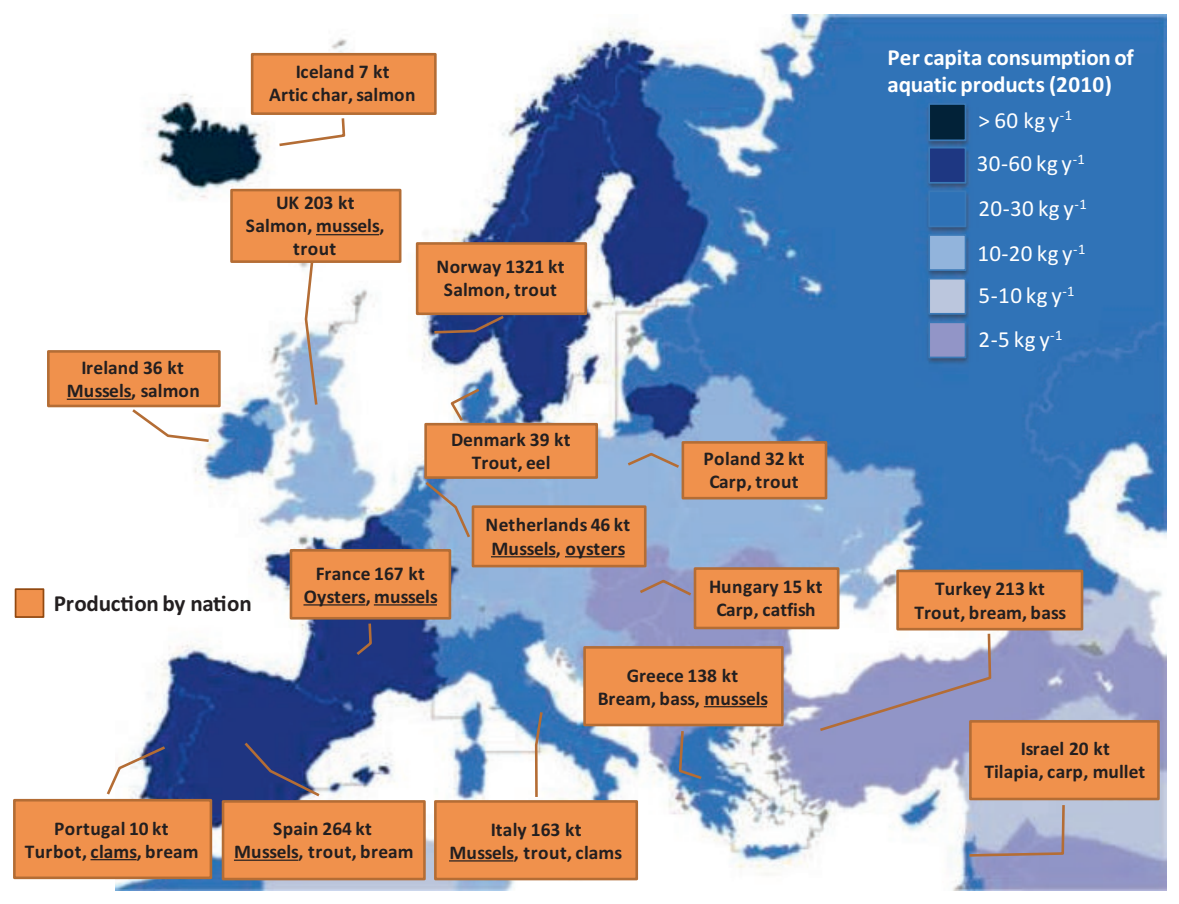

Fig. 27.2 Aquaculture production in Europe (bivalves underlined), illustrating the wide distribution of bivalve aquaculture, and its spatial relevance to top-down nutrient control. The per capita consumption of aquatic products is also shown

(FAO 2016). However, the global numbers include other molluscs such as abalone, snails, limpets, and octopi, not considered here because they are not filter-feedersChina alone produces over $90 \mathrm{kt} \mathrm{year}^{-1}$ of abalone, and almost $112 \mathrm{kt} \mathrm{year}^{-1}$ of the freshwater mystery snail (Bellamia chinensis), which together practically equal all the North American bivalve production.

The coefficients used in Ferreira and Bricker (2016), obtained through the application of the FARM model to the main cultivated bivalve species, were used to calculate the potential net nitrogen removal for the world production of filter-feeding bivalves listed in Table 27.2. In total, about $635 \mathrm{kt} \mathrm{N}$ may be removed annually (Table 27.3), a regulatory service that is unaccounted for but corresponds to almost 192 million population-equivalents. Within a nutrient credit trading framework, this would correspond to a potential minimum value of 7.7 billion USD.

A comparison of nutrient loading and nitrogen offsets by farmed bivalves is given in Table 27.4, broken down by world areas. Aquaculture is a very small contributor to nutrient budgets in the West, both as a source (fed aquaculture, mainly finfish) and a sink (bivalves), due to social licence constraints to expansion. The contribution of marine aquaculture to the total nitrogen loading to the coastal zone ranges from trivial (1.2\% in China) to insignificant $(0.02 \%$ in the United States). However, in both cases, there is a significant input of nitrogen from land-based 
Table 27.2 Bivalve production for major areas of the world (tonnes live weight year ${ }^{-1}$ )

\begin{tabular}{|c|c|c|c|c|c|}
\hline Group, genus, or species & $\begin{array}{l}\text { European } \\
\text { Union }^{\mathrm{a}}\end{array}$ & $\begin{array}{l}\text { United } \\
\text { States }^{\mathrm{b}} \\
\end{array}$ & Canada $^{\mathrm{c}}$ & China $^{\mathrm{b}}$ & Total \\
\hline Oysters & 92,620 & & 12,604 & & 105,224 \\
\hline $\begin{array}{l}\text { Cupped oysters (Crassostrea } \\
s p .)\end{array}$ & 89,870 & 131,849 & & $3,948,817$ & $4,170,536$ \\
\hline Flat oyster $($ O. edulis $)$ & 2750 & 4 & & & 2754 \\
\hline $\begin{array}{l}\text { Mussels (M. edulis, } M \text {. } \\
\text { galloprovincialis) }\end{array}$ & 405,195 & 3127 & 25,464 & 764,395 & $1,198,181$ \\
\hline Scallops & 56 & & 114 & $1,419,956$ & $1,420,126$ \\
\hline Clams, cockles, arkshells & 34,438 & & 1626 & & 36,064 \\
\hline Cockles & 4431 & 1 & & 278,058 & 282,490 \\
\hline Clams & 29,766 & & & & 29,766 \\
\hline Soft clam & 14 & 683 & & & 697 \\
\hline Good clam (V. decussatus) & 5628 & & & & 5628 \\
\hline Carpet shell (V. pullastra) & 339 & & & & 339 \\
\hline Manila clam & 23,779 & 4126 & & $3,735,484$ & $3,763,389$ \\
\hline $\begin{array}{l}\text { Razor clam (Solen sp., } \\
\text { Sinonovacula sp.) }\end{array}$ & 5 & & & 720,466 & 720,471 \\
\hline Quahog (M. mercenaria) & 1 & 27,704 & & & 27,705 \\
\hline Geoduck clam & & 534 & & & 534 \\
\hline Pen shells (Pinnidae) & & & & 15,061 & 15,061 \\
\hline Other & & 51 & 119 & 897,116 & 897,286 \\
\hline Freshwater molluscs & & & & 147,040 & 147,040 \\
\hline Total & $532310^{\mathrm{d}}$ & 168,079 & 39,927 & $11,926,393$ & $12,666,709$ \\
\hline Percentage of total (\%) & 4.2 & 1.3 & 0.3 & 94.2 & 100 \\
\hline
\end{tabular}

aData for 2013, see Ferreira and Bricker (2015) for data sources and national breakdown

${ }^{b}$ Data for 2012, FAO FishStatJ; http://www.fao.org/fishery/statistics/software/fishstatj/en

'Data for 2014, Canadian Department of Fisheries and Oceans (DFO), 2016; http://www.dfo-mpo. gc.ca/stats/aqua/aqua14-eng.htm

dData shown for 2013, updated from the 2011 Eurostat dataset given in Ferreira and Bricker (2016). The major change from 2011 to 2013 was that significant blue mussel production volumes were moved from aquaculture to fisheries. As an example, Eurostat reported Danish blue mussel aquaculture in 2011 as 47,907 t, and reduced it to $560 \mathrm{t}$ in 2013. Though less extreme, reductions were also made to estimates for Germany, The Netherlands, and Ireland. These were not reductions in capacity, but a reclassification. The number given herein agrees well with the European Commission (2016) Common Fisheries Policy report, which gives a total EU aquaculture production of 1,211,259 t for 2013, of which $43.6 \%$ (520,841 t) are molluscs and crustaceans

freshwater fish farming (see footnote, Table 27.4) which is not shown here, since we are only considering coastal systems where a clear link between different loading sources and bivalve aquaculture can be established.

Table 27.4 shows that for Europe, on a mass balance basis, bivalves offset over half the total fed aquaculture nitrogen load, and in Canada, they offset almost $90 \%$ of the $\mathrm{N}$ load from finfish culture. In both the USA and China, the relative role of bivalves in removing the nutrients discharged by finfish culture is far more relevant than in the other areas considered, but the differences in scale of production must be 
Table 27.3 Bivalve nitrogen removal calculated with the FARM model for major areas of the world (tonnes $\mathrm{N}$ year ${ }^{-1}$ )

\begin{tabular}{|c|c|c|c|c|c|}
\hline Group, genus, or species & $\begin{array}{l}\text { European } \\
\text { Union }\end{array}$ & $\begin{array}{l}\text { United } \\
\text { States }\end{array}$ & Canada & China & Total \\
\hline Oysters $^{\mathrm{a}}$ & 9461 & & 1287 & & 10,749 \\
\hline Cupped oysters (Crassostrea sp.) & 3439 & 5045 & & 151,110 & 159,595 \\
\hline Flat oyster (O. edulis) & 105 & 0.2 & & & 105 \\
\hline $\begin{array}{l}\text { Mussels (M. edulis, } M \text {. } \\
\text { galloprovincialis) }{ }^{\mathrm{b}}\end{array}$ & 25,341 & 196 & 1593 & 47,805 & 74,933 \\
\hline Scallops ${ }^{\mathrm{c}}$ & 2 & & 4 & 54,338 & 54,344 \\
\hline Clams, cockles, arkshells ${ }^{\mathrm{d}}$ & 2418 & & 114 & & 2532 \\
\hline Cockles & 311 & 0.1 & & 19,524 & 19,835 \\
\hline Clams & 2090 & & & & 2090 \\
\hline Soft clam & 1 & 48 & & & 49 \\
\hline Good clam (V. decussatus) & 395 & & & & 395 \\
\hline Carpet shell (V. pullastra) & 24 & & & & 24 \\
\hline Manila clam & 1670 & 290 & & 262,293 & 264,252 \\
\hline $\begin{array}{l}\text { Razor clam (Solen sp., Sinonovacula } \\
s p . \text {.) }\end{array}$ & 0.4 & & & 50,589 & 50,589 \\
\hline Quahog (M. mercenaria) & 0.1 & 1945 & & & 1945 \\
\hline Geoduck clam & & 37 & & & 37 \\
\hline Pen shells & & & & 1058 & 1058 \\
\hline Total & 37,222 & 7562 & 2999 & 586,716 & $634499^{\mathrm{e}}$ \\
\hline Percentage of total (\%) & 5.9 & 1.2 & 0.5 & 92.5 & 100 \\
\hline
\end{tabular}

${ }^{a}$ Calculated using an $\mathrm{N}$ removal of $38.2 \mathrm{~kg} \mathrm{~N} \mathrm{t} \mathrm{FW}^{-1}$ year $^{-1}$, from FARM model outputs for Pacific oyster (Ferreira and Bricker 2016)

${ }^{\mathrm{b}}$ Calculated using an average $\mathrm{N}$ removal of $62.5 \mathrm{~kg} \mathrm{~N} \mathrm{t} \mathrm{FW}^{-1}$ year ${ }^{-1}$, by combining FARM model outputs for blue mussel and Mediterranean mussel (Ferreira and Bricker 2016).

${ }^{\mathrm{c}}$ Calculated using Pacific oyster N removal (Ferreira and Bricker 2016), no scallop model available.

${ }^{\mathrm{d} C a l c u l a t e d ~ u s i n g ~ a n ~} \mathrm{~N}$ removal of $70.2 \mathrm{~kg} \mathrm{~N} \mathrm{t} \mathrm{FW}^{-1}$ year ${ }^{-1}$, from FARM model outputs for Manila clam (Ferreira and Bricker 2016).

${ }^{\mathrm{e}}$ Corresponds to $192,272,352$ PEQ year ${ }^{-1}$, which would have a potential value of 7690.89 million $\mathrm{USD}_{\mathrm{Sear}}{ }^{-1}$, using a PEQ conversion factor for land-based removal from Lindahl et al. (2005)

taken into account - the $870 \%$ offset of finfish culture in the US is more due to the very low finfish production than to a significant bivalve production. By contrast, in China, the removal of $587 \times 10^{3} \mathrm{t} \mathrm{N}$ year ${ }^{-1}$ undoubtedly plays a role in mitigating coastal eutrophication.

Although, by definition, in organically extractive aquaculture there is a net removal of particulate organic matter (POM), bivalve culture at a high stocking density in suspended structures such as rafts or longlines may locally impact the bottom in a similar way to finfish cage culture (Grant, pers. com.). Particle consolidation by bivalves into pseudofaeces and faeces might result in faster settling, and therefore part of the phytoplankton nitrogen which might be otherwise be flushed out of an estuary or embayment could be retained within an estuary or bay. 
Table 27.4 Nitrogen loading and offsets for major areas of the world

\begin{tabular}{l|l|l|l|l|l}
\hline & Europe & USA & Canada & China & Total \\
\hline Total N load $\left(10^{3} \mathrm{t} \mathrm{N} \mathrm{year}{ }^{-1}\right)$ & 4142.6 & 3514.0 & 733.3 & 2706.0 & 11095.9 \\
\hline Fed aquaculture N load $\left(10^{3} \mathrm{t} \mathrm{N} \mathrm{year}^{-1}\right)$ & 68.8 & $0.9^{\mathrm{a}}$ & 3.3 & $32.8^{\mathrm{b}}$ & 105.8 \\
\hline Organic extractive N removal $\left(10^{3} \mathrm{t} \mathrm{N} \mathrm{year}^{-1}\right)$ & 37.2 & 7.6 & 3.0 & 586.7 & 634.5 \\
\hline $\begin{array}{l}\text { Proportion of total N load due to fed aquaculture } \\
(\%)\end{array}$ & 1.7 & 0.02 & 0.5 & 1.2 & \\
\hline $\begin{array}{l}\text { Proportion of fed aquaculture N load offset by } \\
\text { bivalves (\%) }\end{array}$ & 54.1 & 870.2 & 89.6 & 1790.8 & \\
\hline Proportion of total N load offset by bivalves (\%) & 0.9 & 0.2 & 0.4 & 21.7 & \\
\hline
\end{tabular}

${ }^{a}$ Only marine aquaculture, mainly salmonids; excludes $229 \times 10^{3} \mathrm{t}$ live weight year ${ }^{-1}$ freshwater production, of which $67 \%$ are channel catfish

${ }^{\mathrm{b}}$ Only marine aquaculture; excludes $27,150 \times 10^{3} \mathrm{t}$ live weight year ${ }^{-1}$ freshwater production, of which $49 \%$ are grass carp, silver carp, and bighead carp

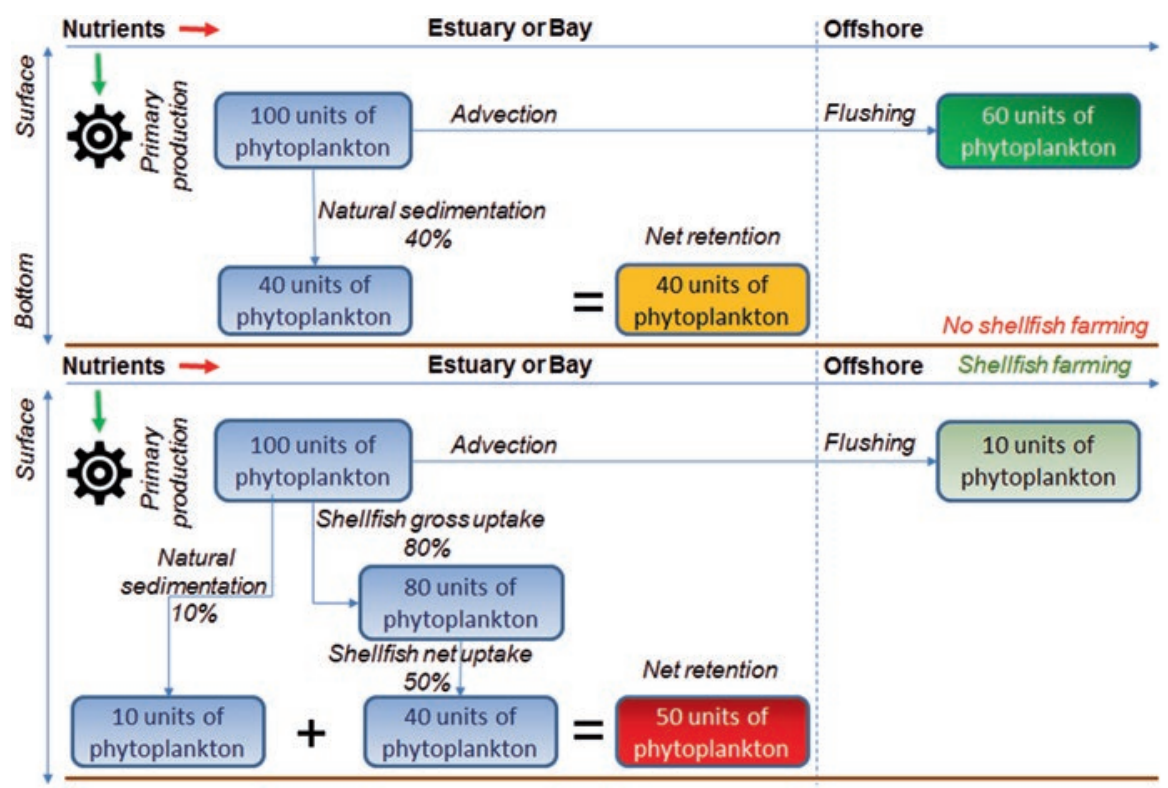

Fig. 27.3 Potential net phytoplanton nutrient retention in an estuary or bay where large-scale bivalve farming is practised

Figure 27.3 shows the conceptual representation for a system where, with no top-down control by bivalves (upper pane), there would be a net export of 60 phytoplankton 'units' from the system to offshore waters, and a retention of 40 units due to sedimentation. In the lower pane, bivalves would remove 80 units through gross uptake, of which 50\% (40 units) are lost to the sediment through pseudofaeces and faeces, both of which sediment rapidly within the system. A further 10 units are 
lost through natural sedimentation of phytoplankton and remain within the estuary or bay, and therefore 10 units are exported offshore. As a consequence, although there would be a net removal (top-down control of phytoplankton) of 40 units of POM, which are used for bivalve growth, 50 units of POM are nevertheless retained in the estuarine sediment, i.e. $25 \%$ more than in the non-bivalve model. We emphasize only that this may occur, and underscore that it should not be seen as a typical situation. However, this conceptual example helps to illustrate that the use of bivalve aquaculture in nutrient management is a complex issue, and must be carefully considered.

\subsection{Trading Mechanisms}

\subsubsection{How Does a Trading Program Work?}

Sixty-five percent of US estuaries and many in the EU and elsewhere are impacted by nutrient loads and do not meet established water quality standards (e.g. Bricker et al. 2007; HELCOM 2010, 2014). Legislation such as the EU WFD and US Clean Water Act establish a basis for regulating pollutants from both point and non-point sources. Despite these regulations and attempts to reduce nutrient discharges, many waterbodies remain impaired. This situation has created increasing interest in the concept of nutrient credit trading as a means of achieving water quality goals in a timely and cost-effective manner (USEPA 2004b). In the US, a Total Maximum Daily Load (TMDL; USEPA 2017) analysis is conducted on a waterbody that does not meet water quality standards to determine the maximum amount of a pollutant (nutrients) that can be discharged to the waterbody and still meet water quality goals. That maximum, or cap, is used to allocate maximum allowable loads from regulated point sources (e.g. WWTF) discharging to the waterbody.

A nutrient trading program provides the opportunity for point-source dischargers who reduce their nutrient loads below those allocated target levels to sell their surplus reductions or nutrient 'credits' to other dischargers in the same watershed who are unable or face higher-cost nutrient reduction options. A credit is the difference between the discharge allowance for a point source and the measured discharge from that source. In the case of unregulated non-point sources, a credit or offset is a nutrient reduction by that source that must be certified by a regulatory agency and is referred to as a Best Management Practice (BMP). Non-point source BMPs include agricultural nutrient management practices (e.g. cover crops, riparian buffers), wetland construction, and urban stormwater controls. Trading programs are designed to establish a market-based approach to nutrient management by providing economic incentives for achieving nutrient load reductions (Lindahl et al. 2005; Jones et al. 2010; Lal 2010; Stephenson et al. 2010). The overall goal of trading programs is to meet regulatory requirements at lower overall costs, but they can potentially generate greater environmental benefits than would be achieved under 
traditional regulation, and may also address and raise awareness of other sources contributing to water quality degradation.

Nutrient credit trading programs are already a reality in parts of the US (Lal 2010; Branosky et al. 2011; Ferreira et al. 2011; STAC 2013). The Connecticut Nitrogen Credit Exchange (CNCE) is a nutrient trading program created in 2002 to address nutrient-related hypoxia conditions in Long Island Sound (LIS), where the state acts as broker and price setter. This is one of the few mature and successful examples of water quality credit trading. The program provided an alternative compliance mechanism for 79 WWTFs throughout the state, with 15.5 million nitrogen credits bought and sold during 2002-2009, representing a value of \$45.9 million US. The cost savings of the exchange's credit trading were estimated at $\$ 300-\$ 400$ million (CT DEP 2010), compared to improving nitrogen removal technologies.

As more facilities successfully attained their final waste load allocations, the number of buyers of nitrogen credits decreased, though there are still some buyers and the program continues (M. Tedesco, Long Island Sound Study, pers. com.). It is important to note that the CNCE includes only point sources, though a mechanism for including non-point sources to meet more stringent future allocations is being discussed.

\subsubsection{Non-point Source Trading Challenges}

The inclusion of non-point sources in credit trading programs is intended to increase flexibility and provide additional options for regulated sources to achieve reductions through trades with unregulated non-point sources. The U.S. Environmental Protection Agency's (EPA) 2008 national water quality trading policy supports creation of non-point source water quality trading credits through agricultural BMPs, creation and restoration of wetlands, stormwater control construction, and more recently have included nutrient assimilation offsets that remove nutrients directly from the water, such as bivalve aquaculture (USEPA 2008a).

Because trading programs must ensure that water quality goals are met, regulators must be certain that the off-site non-point source load reduction will yield similar or superior water quality conditions. Trading programs must ensure equivalent outcomes when controls take place at different nutrient sources and locations in the watershed (Stephenson and Shabman 2017a). Unlike the success demonstrated by the point-to-point trading in LIS, very few trades have been made in the many nonpoint source trading programs developed, due to the high costs of assuring equivalence between point and non-point sources (Stephenson and Shabman 2017a; STAC 2013, Ribaudo and Gottlieb 2011).

Several regulatory requirements to assure equivalence contribute to the high costs of purchasing agricultural non-point credits, may hinder establishment of trading programs. These include: trading ratios, setting of baselines, and quantification and verification of non-point source control effectiveness (Ribaudo and Gottlieb 2011; Stephenson and Shabman 2017b). 
Transaction costs for generating credits, and for monitoring and enforcement of crediting projects, may increase production costs (DeBoe and Stephenson 2016). Costs associated with generating credits range from \$1865-\$8705 per three-year project, depending on the complexity of the contract (DeBoe and Stephenson 2016). The cost of monitoring and verification of reduction performance, once controls are implemented, varies depending on the type of monitoring and verification (onsite vs remote), as well as the project duration (permanent or term credits) and frequency of required verification (i.e. 5 year vs 1 year verification). DeBoe and Stephenson (2016) describe potential $82-96 \%$ reductions in monitoring and verification costs with self-reporting and remote monitoring. Comparison of annualized transaction costs for projects generating permanent credits $(\$ 257), 10$ year fixed term credits (\$534-\$864) and 3 year fixed term credits (\$1801-\$4144) are considered modest due to the type of activity being credited (mostly land conversion), though working land BMPs may cost more. Thus, costs are currently not seen as a barrier to trade (DeBoe and Stephenson 2016).

A further analysis was done to evaluate other reasons for the lack of non-point source trading using three well-developed Virginia nutrient trading programs (Stephenson and Shabman 2017b). The analysis included industrial and municipal WWTF, municipal stormwater programs, and land development programs and showed that obstacles to nutrient credit trading are regulatory:

1. Regulatory requirements and trade restrictions where on-site nutrient reductions at permitted sources (called sequencing) are preferred. Permittees are required to operate installed capital equipment to design capability to meet mandatory effluent concentrations regardless of possible cost advantages trading with other sources, the state prioritizes point-to-point trading, and land development requires $75 \%$ of nutrient control to occur on-site.

2. Overlapping regulatory requirements where (i) WWTF have non-transferable requirements for the total volume of stormwater runoff from a site, and those lower discharges result in nutrient reductions; (ii) proposed wastewater re-use; and (iii) aquifer recharge, will further reduce nutrient loads. Water quality improvement grants pay 30-90\% of WWTF upgrade costs reducing the need for off-site credits.

3. Compliance preference of regulated dischargers where: regulated sources prefer to achieve compliance with on-site technologies and control practices where the risk of non-compliance is under their direct control.

Issues that suppress point-source demand for non-point source credits in Virginia are representative of conditions found elsewhere in the US. For decades, federal and state programs have provided farmers with financial assistance ('cost-share') to implement specific agricultural practices that reduce pollutant loads. These programs pay farmers to implement practices, rather than paying directly for pollutant load reductions. Recent efforts to boost the supply of non-point source load reduction credits for trading demonstrates that non-point source practices can be quantified and certified into estimated load reductions. If governments would apply these non-point source crediting tools and methods along with competitive bid processes 
to identify low cost non-point source options with public non-point source funding, non-point source trading would thrive (Stephenson and Shabman 2017b).

\subsubsection{Inclusion of Bivalves in Credit Trading Programs}

As shown above, there is compelling evidence in support of the use of bivalves as a nutrient removal BMP for inclusion in nutrient credit trading. The documented nutrient removal capacity shown in multiple studies (e.g. Lindahl et al. 2005; Kellogg et al. 2014; Petersen et al. 2014; Rose et al. 2015) is as effective as BMPs that have already been approved for use in trading programs. Table 27.5 shows that annualized nitrogen removal by bivalve farms compared favourably to removal by stormwater control measures, based on two lines of evidence: (i) the nitrogen removal per unit area was highest for bivalve and gravel wetlands, all other

Table 27.5 Annual nitrogen removal $\left(\mathrm{kg} \mathrm{ha}^{-1}\right)$ by different types of stormwater control measures, installed at the University of New Hampshire Stormwater Center, and by agricultural best management practices in the Chesapeake Bay watershed, as approved by the Virginia Department of Environmental Quality

\begin{tabular}{|c|c|c|}
\hline Management practice & $\begin{array}{l}\text { Annual nitrogen removal } \\
\left(\mathrm{kg} \mathrm{ha}^{-1}\right)^{\mathrm{a}}\end{array}$ & Cost $\left(€ \mathrm{~kg}^{-1} \mathrm{~N}\right)^{2}$ \\
\hline Bivalve farms & $118-1520(819)$ & $11-278(145)$ \\
\hline \multicolumn{2}{|c|}{ Stormwater control measures (modified from Houle et al. 2013) } & $56-6720(3388)$ \\
\hline Vegetated swale & 0 & \\
\hline Wet pond & 293 & \\
\hline Dry pond & 222 & \\
\hline Sand filter & 0 & \\
\hline Gravel wetland & 1111 & $1.1-396(199)$ \\
\hline Porous asphalt & 0 & \\
\hline \multicolumn{2}{|c|}{$\begin{array}{l}\text { Approved agricultural BMP (modified from Stephenson et al. 2010) } \\
\text { minimum-maximum }\end{array}$} & $0.2-870(435)$ \\
\hline Early cover crop & $0.04-1.23(0.63)$ & \\
\hline $15 \% \mathrm{~N}$ reduction & $1.24-4.72(2.98)$ & \\
\hline Continuous no-till & $0.80-2.01(1.41)$ & \\
\hline $15 \% \mathrm{~N}$ reduction + continuous no-till & $1.85-5.62(3.74)$ & \\
\hline Crop to forestland conversion & $4.16-12.98(8.57)$ & \\
\hline Wastewater treatment upgrades & & $\begin{array}{l}0.9-14,093 \\
(7047)\end{array}$ \\
\hline Other & & $5.2-404(205)$ \\
\hline
\end{tabular}

The final column provides data on reported costs for six categories of non-point-source nitrogen removal strategies. Each strategy includes a range of subcategories. Reported costs have been converted to $€ \mathrm{~kg}^{-1} \mathrm{~N}$ (adapted from Rose et al. 2015). Mean values are given in brackets where applicable

${ }^{a}$ For a breakdown of detail for ranges provided in this column, please see online supplementary material in Rose et al. (2015) 
stormwater control measures were far less effective; (ii) the implementation cost per unit nitrogen is lowest for bivalves, followed by wetlands (37\% higher). Taken together, bivalve aquaculture and wetlands are the most promising BMPs in terms of both competitive cost and nitrogen removal per unit area.

In general, nutrient removal by bivalve farms, and by specific stormwater control measures such as wetlands and ponds, was far higher than the removal reported for agricultural BMPs (Rose et al. 2015); in addition, the unit cost for those options was less than half that of agricultural BMPs. This comparison suggests that both stormwater control measures and bivalve aquaculture would be more desirable for nonpoint-source credit trading than agricultural practices.

Rose et al. (2015) expanded the analysis to evaluate comparative costs for nitrogen removal strategies (Table 27.5). The last column in the table shows that nonpoint source credits produced by cultivated bivalves are similar to those produced by agricultural non-point nutrient management strategies and both are more costeffective than urban stormwater strategies and wastewater treatment upgrades. This analysis of removal efficiencies and cost-effectiveness confirms that bivalves are a promising nutrient removal strategy that could potentially be successfully used in a credit trading program.

A recent analysis of agricultural and assimilative service BMPs further supports the potential successful use of bivalves in trading programs. Stephenson and Shabman (2017a) evaluated approved agricultural BMPs (structural i.e. riparian buffers, grass filter strips; management i.e. cover crops, tillage practices, nutrient management, and land conversion) and aquatic plant biomass creation and harvest, bivalve aquaculture, stream restoration, and wetland restoration and creation. Five water quality criteria were evaluated, including quantification certainty, temporal matching, additionality, and leakage. Table 27.6 provides results of the assessment and shows that assimilation reduction strategies such as biomass harvest and bivalve aquaculture provide more assurances of equivalence than agricultural non-point sources.

There is high certainty in quantification with the nutrient harvest technologies, as well as better temporal matching, and lower non-additionality and leakage risks than in agricultural non-point source projects (Stephenson and Shabman 2017a). Agricultural BMPs present challenges to equivalency due to uncertain quantification of nutrient reduction performance, temporal mismatching of loads, and leakage. Osmond et al. (2012) also note the uncertainties associated with quantification of agricultural BMPs due to deficiencies in existing modelling tools, and suggest that due either to problems with modelling or water quality data, or both, the models grossly overestimate the effectiveness of conservation practices. It must be noted, however, that there are potential uncertainties associated with bivalve culture, and therefore with its potential role in nutrient management. Examples include HAB- or disease-related mortalities, and loss of gear and stock in extreme weather, which can result in an increase of nutrients in the water column.

Nutrient assimilation credits have the potential to increase both the quantity and the quality of credits used by regulated point sources to achieve compliance. If they can provide more certain water quality outcomes, then a strong case can be made for 
Table 27.6 Summary of water quality equivalence of nutrient credit trading options

\begin{tabular}{|c|c|c|c|c|}
\hline & $\begin{array}{l}\text { Quantification of } \\
\text { outcome }^{\mathrm{a}}\end{array}$ & Temporal matching ${ }^{\mathrm{b}}$ & $\begin{array}{l}\text { Spatial } \\
\text { redistribution }\end{array}$ & Leakage $^{\mathrm{d}}$ \\
\hline \multicolumn{5}{|l|}{$\begin{array}{l}\text { Non-point } \\
\text { source credits }\end{array}$} \\
\hline $\begin{array}{l}\text { Structural } \\
\text { agricultural } \\
\text { BMPs } \\
\end{array}$ & $\begin{array}{l}\text { Observed } \\
\text { behaviours: } \\
\text { Modelled outcomes }\end{array}$ & $\begin{array}{l}\text { Stochastic loads, } \\
\text { load averaging across } \\
\text { time }\end{array}$ & $\begin{array}{l}\text { Requires delivery } \\
\text { attenuation } \\
\text { estimates }\end{array}$ & $\begin{array}{l}\text { Some } \\
\text { leakage } \\
\text { potential }\end{array}$ \\
\hline $\begin{array}{l}\text { Management } \\
\text { agricultural } \\
\text { BMPs }\end{array}$ & $\begin{array}{l}\text { Observed or } \\
\text { reported behaviors: } \\
\text { Modelled outcomes }\end{array}$ & $\begin{array}{l}\text { Stochastic loads, } \\
\text { load averaging across } \\
\text { time }\end{array}$ & $\begin{array}{l}\text { Requires delivery } \\
\text { attenuation } \\
\text { estimates }\end{array}$ & $\begin{array}{l}\text { Some } \\
\text { leakage } \\
\text { potential }\end{array}$ \\
\hline Land conversion & $\begin{array}{l}\text { Observed } \\
\text { behaviors: } \\
\text { Modelled outcomes }\end{array}$ & $\begin{array}{l}\text { Stochastic loads, } \\
\text { load averaging across } \\
\text { time }\end{array}$ & $\begin{array}{l}\text { Requires delivery } \\
\text { attenuation } \\
\text { estimates }\end{array}$ & $\begin{array}{l}\text { Some } \\
\text { leakage } \\
\text { potential }\end{array}$ \\
\hline $\begin{array}{l}\text { Nutrient } \\
\text { assimilation } \\
\text { wetlands }\end{array}$ & $\begin{array}{l}\text { Measured or } \\
\text { Modelled outcomes }\end{array}$ & $\begin{array}{l}\text { Potentially stochastic } \\
\text { loads, load averaging } \\
\text { across time }\end{array}$ & $\begin{array}{l}\text { Requires delivery } \\
\text { attenuation } \\
\text { estimates }\end{array}$ & Minimal \\
\hline $\begin{array}{l}\text { Bivalve } \\
\text { aquaculture }\end{array}$ & $\begin{array}{l}\text { Biomass harvest: } \\
\text { Measure burial/ } \\
\text { denitrification: } \\
\text { model }\end{array}$ & $\begin{array}{l}\text { Temporal matching } \\
\text { of load reductions } \\
\text { with buyers }\end{array}$ & $\begin{array}{l}\text { Requires delivery } \\
\text { attenuation } \\
\text { estimates }\end{array}$ & $\begin{array}{l}\text { Some } \\
\text { leakage } \\
\text { potential }\end{array}$ \\
\hline Algal harvest & Measure outcomes & $\begin{array}{l}\text { Temporal matching } \\
\text { of load reductions } \\
\text { with buyers }\end{array}$ & $\begin{array}{l}\text { May require } \\
\text { delivery } \\
\text { attenuation } \\
\text { estimates }\end{array}$ & Minimal \\
\hline $\begin{array}{l}\text { Seaweed and } \\
\text { aquatic plant } \\
\text { harvest }\end{array}$ & Measure outcomes & $\begin{array}{l}\text { Temporal matching } \\
\text { of load reductions } \\
\text { with buyers }\end{array}$ & $\begin{array}{l}\text { May require } \\
\text { delivery } \\
\text { attenuation } \\
\text { estimates }\end{array}$ & Minimal \\
\hline $\begin{array}{l}\text { Stream } \\
\text { restoration }\end{array}$ & Model outcomes & $\begin{array}{l}\text { Potentially stochastic } \\
\text { loads, load averaging } \\
\text { across time }\end{array}$ & $\begin{array}{l}\text { Requires delivery } \\
\text { attenuation } \\
\text { estimates }\end{array}$ & Minimal \\
\hline
\end{tabular}

Adapted from Stephenson and Shabman (2017a)

A glossary of terms is provided in the notes for this table

${ }^{\text {a }}$ Quantification of nutrient reduction credits should be estimated with a similar level of certainty. A nutrient credit is defined as a nutrient load reduction, relative to a baseline, over a specific period of time (e.g., kg of nitrogen per year). For example, point sources typically quantify nutrient loads by direct measurement of flow and sampling of effluent concentrations. Non-point source credits are more difficult to quantify

${ }^{b}$ Temporal matching means that the timing of the load reduction from the credit is the same as the timing of the point-source load being offset. When the timing is the same, there is no risk of an adverse effect on water quality conditions as a result of the trade

'Spatial redistribution requires trading programs to define a specific geographic location in the watershed where water quality outcomes will be compared and evaluated for equivalency. Nutrient credit trading spatially redistributes nutrient loads actions across a watershed. For example, a trading program may allow a point source to buy credits from a non-point source regardless of the location as long as 'delivered loads' to the watershed impairment point (such as a downstream estuary) is the same between buyer and seller. A point source could buy credits from a downstream non-point source, thereby increasing nutrient loads in the watershed between the point and non-point source, but producing equivalent delivered loads below the non-point source. Note that trading program provisions explicitly prohibit transactions that would impair local water quality along the delivery route ${ }^{\mathrm{d}}$ Leakage occurs when a nutrient credit trade produces another form of unaccounted increase in nutrient loads 
their inclusion in nutrient trading programs. Nutrient assimilation credits, relative to agricultural non-point source load reductions, can offer greater assurances of equivalence for trades with regulated point sources.

\subsubsection{Oyster BMP in Chesapeake Bay}

Inclusion of bivalves in trading programs is viewed as a positive addition to nutrient trading programs (Stephenson et al. 2010; Rose et al. 2014; Stephenson and Shabman 2017a) but until recently they were not an approved BMP and thus could not be included. Recently, the Chesapeake Bay Program Oyster BMP Expert Panel evaluated and approved nutrient removal reduction by cultured oysters and developed a framework for crediting and verification for application of an oyster BMP (Oyster BMP Expert Panel 2016). The BMP is for harvested tissue only (Table 27.7); recommendations for development of a BMP for oyster shell, denitrification, and burial are anticipated in 2017.

Recommended default estimates for nutrient credits production by harvested oyster tissue were derived from oyster growth (shell height to dry tissue weight regressions) and tissue nutrient concentration data from several Chesapeake Bay locations (Oyster BMP Panel 2016). Differences in biomass between diploid and triploid oysters warranted the use of separate regression equations. The 50th quantile was used to conservatively account for differences in culture method and type (off-bottom/on-bottom, hatchery-produced/wild). The final default recommendations for average nutrient content of $8.2 \%$ nitrogen and $0.9 \%$ phosphorus, based on dry tissue, are applied regardless of location or ploidy to avoid biases (i.e. site specific, variability in time). However, the framework allows for development of site-

Table 27.7 Recommendations for crediting of nitrogen and phosphorus removal by harvested oyster tissue in Chesapeake Bay

\begin{tabular}{l|l|l}
\hline Best Management Practice (BMP) Name & $\begin{array}{l}\text { lbs N reduced per } 10^{6} \\
\text { oysters harvested }\end{array}$ & $\begin{array}{l}\text { lbs P reduced per } 10^{6} \\
\text { oysters harvested }\end{array}$ \\
\hline Diploid Oyster Aquaculture 2.25 Inches & 110 & 22 \\
\hline Diploid Oyster Aquaculture 3.0 Inches & 198 & 22 \\
\hline Diploid Oyster Aquaculture 4.0 Inches & 331 & 44 \\
\hline Diploid Oyster Aquaculture 5.0 Inches & 485 & 44 \\
\hline Diploid Oyster Aquaculture $\geq$ 5.5 Inches & 683 & 66 \\
\hline Triploid Oyster Aquaculture 2.25 Inches & 132 & 22 \\
\hline Triploid Oyster Aquaculture 3.0 Inches & 287 & 22 \\
\hline Triploid Oyster Aquaculture 4.0 Inches & 573 & 66 \\
\hline Triploid Oyster Aquaculture 5.0 Inches & 970 & 110 \\
\hline Triploid Oyster Aquaculture $\geq$ 5.5 Inches & 1,477 & 154 \\
\hline Site-Specific Monitored Oyster Aquaculture & N/A & N/A \\
\hline Adapted from Oyste BMP Pan & &
\end{tabular}

Adapted from Oyster BMP Panel (2016) 
specific removal rates by interested growers, in conjunction with the state and the Chesapeake Bay Partnership with costs assumed by the grower.

The importance of these recommendations is that states can now legally use nitrogen and phosphorus removed in harvested oyster tissue as a BMP in trading programs within the Chesapeake Bay Watershed, with potential use by other states that support oyster growth. At present, credits earned would count toward nutrient reductions required by the Chesapeake Bay TMDL, i.e. nutrient pollutant clean-up plan-although full inclusion in trading programs requires additional discussion, this is an encouraging step, and the use of bivalve BMPs for regulatory compliance should be encouraged.

\subsubsection{Bivalve Aquaculture for Water Quality Improvement in Massachusetts}

The successful inclusion of bivalves for nutrient water quality compliance has been demonstrated in the town of Mashpee, Massachusetts. As part of a Comprehensive Watershed Nitrogen Management Plan (CWNMP) the plan incorporates several traditional nitrogen reduction approaches and the harvest of cultivated Eastern oysters (Crassostrea virginica) and hard clams (quahogs; Mercenaria mercenaria) to meet TMDL water quality goals and restore bivalve resources (Town of Mashpee Sewer Commission 2015). Comparison of estimated costs (Net Present Value - NPV) for bivalve implementation ( $\$ 22$ million NPV) and sewer mains, pumping stations, and road construction for collection systems ( $\$ 80$ million NPV) shows significant savings are expected from inclusion of aquaculture. Other advantages are that the bivalves remove nitrogen from the water column by filtering organic particulates, the capital costs are lower ( $\$ 180$ million for Phase 1 with bivalves, $\$ 360$ million without), it helps restore bivalve resources and has the potential to generate other positive impacts related to habitat. Some disadvantages are that only watersheds with appropriate habitat can be targeted, long-term performance is unknown, predators and diseases may impact performance, long-term maintenance is unknown, annual seeding of bivalve beds may be required, and bacterial pathogens from septic system effluents may not be addressed.

Mashpee's GIS Department mapped the bivalve habitat based on GPS data collected from the estuaries, and determined that there is sufficient habitat to support the proposed densities of bivalves. In samples from Mashpee harvest areas, both clams and oysters were found to have $0.5 \%$ nitrogen. Thus, a 3.5 -inch $100 \mathrm{~g}$ harvest size oyster would represent removal of $0.5 \mathrm{~g} \mathrm{~N}$, and a $60 \mathrm{~g}$ harvest size clam would remove $0.3 \mathrm{~g} \mathrm{~N}$ (Reitsma et al. 2016). The plan targets harvest of 9 million oysters and 26.5 million clams to remove a total of 12.6 metric tons of nitrogen, $73 \%$ of the nitrogen reduction required by the TMDL. This is considered a conservative estimate since it does not include potentially significant losses from denitrification or burial (Kellogg et al. 2013). It will be a challenge to maintain annual bivalve harvest 
at these levels, but the plan accommodates annual seeding if necessary to produce the harvest necessary to include aquaculture as a nutrient management option.

Other more traditional management measures like WWTFs will be much slower to come online and will only reach full build-out if aquaculture fails. After implementation, performance will be evaluated every 5 years. Bivalve aquaculture holds great promise in helping to reach water quality goals affordably and in compliance with the state $208^{3}$ water quality management plan requirements. The Mashpee CWNMP is an example of how to include bivalves in comprehensive management plans. Through programs such as this, water quality compliance will be successfully achieved with the added benefit of supporting domestic production of seafood.

\subsubsection{Indicators and Assessment Methodologies}

Water quality trading (WQT) mechanisms were first proposed by Dales (1968), and gained traction in the US during the 1980s and 1990s, as water authorities reviewed management options for meeting TMDLs (Shortle 2013). At the beginning of this century, the US EPA began to support WQT both technically and financially, and nutrient credit trading developed as a concept (e.g. Stephenson et al. 2010), and has subsequently been implemented to some degree, largely in the United States. The Connecticut Department of Environmental Protection began its participation in a watershed-scale trading programme in 2002, largely because of concerns related to eutrophication in LIS: this is a chronic issue in LIS, attributed to excessive nutrient loading, and manifests itself e.g. through low dissolved oxygen-a secondary, or well developed, indicator of eutrophication (Fig. 27.4). For the western area of LIS, hypoxia, i.e. dissolved oxygen values lower than $3.5 \mathrm{mg} \mathrm{L}^{-1}$, has been a problem for 90-100\% of the period between 1991 and 2008, and has been recognized as a serious water quality impairment since long before that.

Rice and Stewart (2013) report spring chlorophyll peaks in LIS averaging $8.9 \mu \mathrm{g} \mathrm{L}^{-1}$ for the period 1995-2010, down from $25.3 \mu \mathrm{g} \mathrm{L}^{-1}$ in previous decades, which suggests that nutrient source control has been effective in reducing primary symptoms of eutrophication. Nevertheless, as seen in Fig. 27.4, this appears to be insufficient to reverse hypoxia, although the spatial extent has been reduced from $800 \mathrm{~km}^{2}$ in 1987 to $330 \mathrm{~km}^{2}$ in 2002 (Ferreira et al. 2007b).

The inclusion of filter-feeding bivalves in nutrient credit trading programmes is at best incipient, and has only been examined as a management tool in the United States (e.g. Stephenson et al. 2010; STAC 2013; Oyster BMP Expert Panel 2016). As discussed in the previous section, the emphasis has been on the removal of nitrogen from the receiving water by bivalves, with a possible extension to phosphorus, should $\mathrm{P}$ be relevant as a limiting nutrient.

The premise is that source control of $\mathrm{N}$ or $\mathrm{P}$ loading will lead to a reduction in eutrophication symptoms, e.g. lower concentration maxima of phytoplankton

${ }^{3}$ The 208 programme is a state of Massachusetts water quality management plan. 


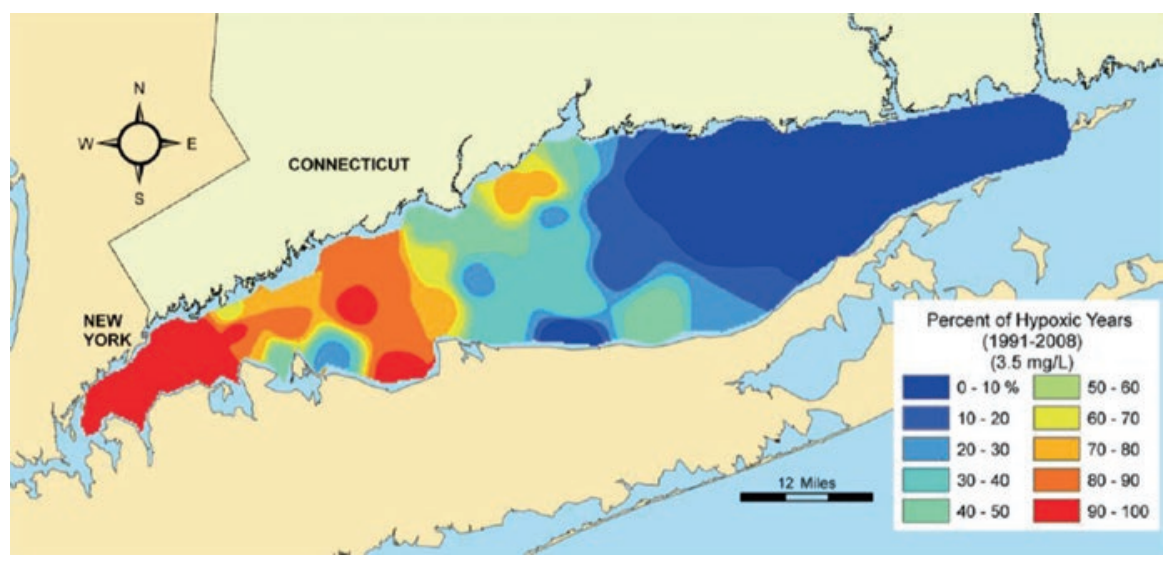

Fig. 27.4 Hypoxia in Long Island Sound: a motivation for nutrient trading schemes for eutrophication management

blooms, and smaller spatial and temporal extent of impairment. However, the key effect of bivalve filter-feeders is to attenuate direct symptoms, rather than to reduce nutrient load - this attenuation can be (qualitatively) evaluated by means of indicators such as water clarity (e.g. Cranford, this volume).

Although at present nitrogen removal is used as a currency to assess the regulatory ecosystem services of bivalves with respect to nutrient control, emphasis could instead be placed on how source control of emissions compares with top-down control, in terms of the reduction of symptoms. From the perspective of eutrophication management, the relevant indicator is not the change in the causative factor, i.e. the nutrient load (and its associated valuation or cost) but the change in the relevant target variables, such as chlorophyll and dissolved oxygen. If we select chlorophyll $(\alpha)$ as a management indicator in an estuary or bay, as is the case in the US (Bricker et al. 2008; USEPA 2008b), EU (WFD, see Ferreira et al. 2006; MSFD, see Ferreira et al. 2011), and elsewhere (see reviews in Borja et al. 2008; Zaldivar et al. 2008), an objective function for chlorophyll reduction $\alpha$ could be written as:

$$
\alpha=\min \{f(\lambda,,, \mu,, \rho,,, \phi)\}
$$

where $\lambda$ is the nutrient loading, $\mu$ is the physical exchange (advection and diffusion), $\rho$ is primary production, and $\phi$ is bivalve filtration. These variables (and others) have an effect on chlorophyll concentration, but some, such as physical exchange, are not amenable to management measures-however, $\mu$ may strongly condition the value of $\alpha$, particularly in high energy systems, because it is a key determinant of system susceptibility, influencing both water turnover and light climate (the latter particularly when there is strong benthic-pelagic coupling).

An analysis of 1100 chlorophyll and Total Particulate Matter (TPM) measurements in LIS for the period 2000-2002, including surface, mid-water, and bottom 
samples (data supplied by J. Rose, NOAA) shows that phytoplankton, normalised as POM and expressed as percentage of TPM, ${ }^{4}$ averages $7.8 \%$, with a high coefficient of variation (147\%). Not only is the chlorophyll signal often masked by other components of TPM, i.e. detrital POM and particulate inorganic matter (PIM), but there is no way to connect the measurements with the fluxes that generate them, i.e. advection and dispersion, sediment-water interactions, and biological sources and sinks such as primary production, bivalve filtration (Eq. 27.1), and zooplankton grazing. A reduction of suspended particulate matter (TPM) in the water column can therefore be considered a potential indicator of lower phytoplankton biomass, but there is typically a very low signal to noise ratio (e.g. in LIS the two variables show a very poor correlation, with $\mathrm{r}=0.19$ ), and source apportionment is not possible.

Although water quality measurements cannot be used to assess the relative influence of emissions control and bivalve drawdown on chlorophyll concentrations in the receiving water, ecosystem models allow a comparison to be made, provided that such models (i) explicitly simulate the relevant state variables and processes; (ii) simulate nutrient discharge from the catchment as part of the modelling framework, allowing different source-control scenarios to be compared with changes in bivalve stocking density.

A modelling framework of this type (Ferreira et al. 2016) typically includes the elements shown in Fig. 27.5, and simulates nutrient loading from the catchment, water circulation and exchange with the ocean, pelagic and benthic primary production, bivalve growth by means of some form of individual-based modelling (IBM),

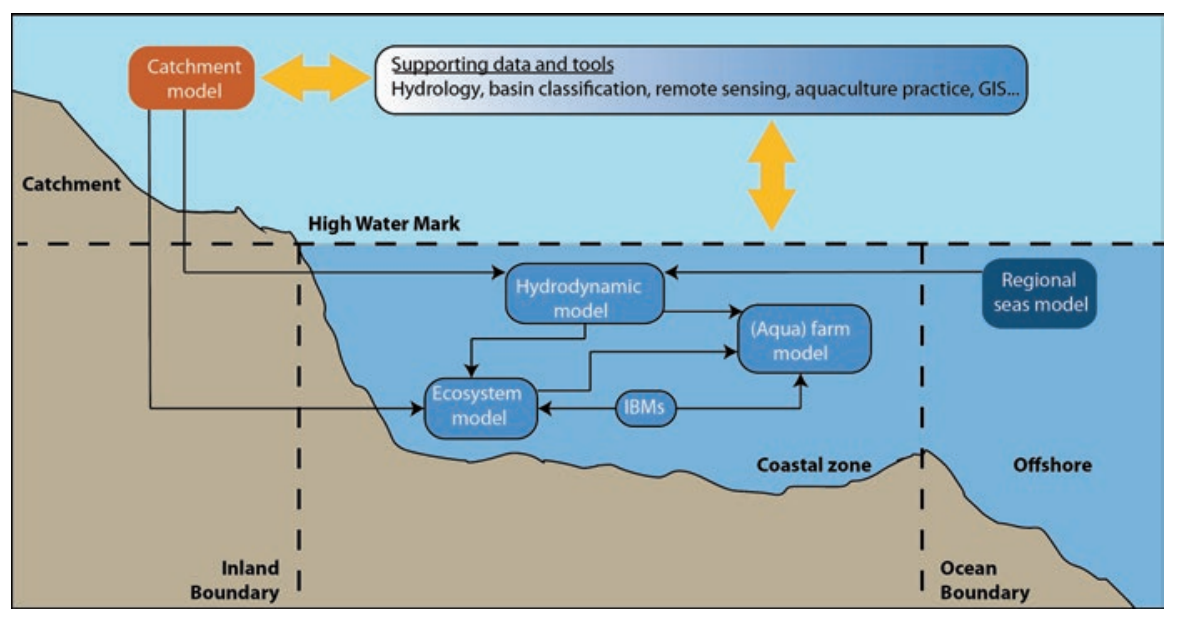

Fig. 27.5 Multi-model simulation framework applied for coastal systems analysis

\footnotetext{
${ }^{4}$ Converted to POM (mg L $\left.{ }^{-1}\right)$ using a C:chl ratio of 50, and a POC:POM ratio of 0.38 .
} 
and bivalve population dynamics, including harvesting of the marketable cohort (see Ferreira et al. 2008, and Nobre et al. 2010, for examples from Europe and Asia).

Figure 27.6 illustrates the application of this modelling framework to Lough Foyle, a large $\left(179 \mathrm{~km}^{2}\right)$ estuary that forms the northern border between Northern Ireland (UK) and Ireland. Twenty percent of the lough is intertidal, and there is a substantial and centuries-old production of bivalves, including the blue mussel Mytilus edulis, the European oyster Ostrea edulis, and more recently the Pacific oyster Crassostrea gigas.

The modelling framework is typically run for a decadal period, allowing the integration of multiple culture cycles (typically of the order of 2-3 years), and the effect on chlorophyll concentrations in different parts of the Foyle of 'switching' bivalve cultivation on or off is shown in Fig. 27.6. The model results suggest a strong top-down control of phytoplankton blooms, with typical draw-down of 2-8 $\mu \mathrm{g} \mathrm{L} \mathrm{L}^{-1}$ during the spring-summer bloom periods; however, at the head of the estuary, this effect may be substantially greater, reaching $16 \mu \mathrm{g} \mathrm{L}^{-1}$ during the spring. Lough Foyle is particularly interesting from a regulatory perspective, because over $98 \%$ of the nitrogen loading to the estuary is derived from diffuse sources within the catchment (Nunes and Ferreira 2016). Phytoplankton growth thus depends little on urban nutrient sources, which means that excessive algal blooms cannot easily be controlled at source by nutrient removal, since that would require substantial changes to agricultural practices such as fertilizer applicationthese are both costly and socially unpopular.

In this example, bivalves therefore provide an important contribution to nutrient management and legal compliance, based on WFD biological quality elements

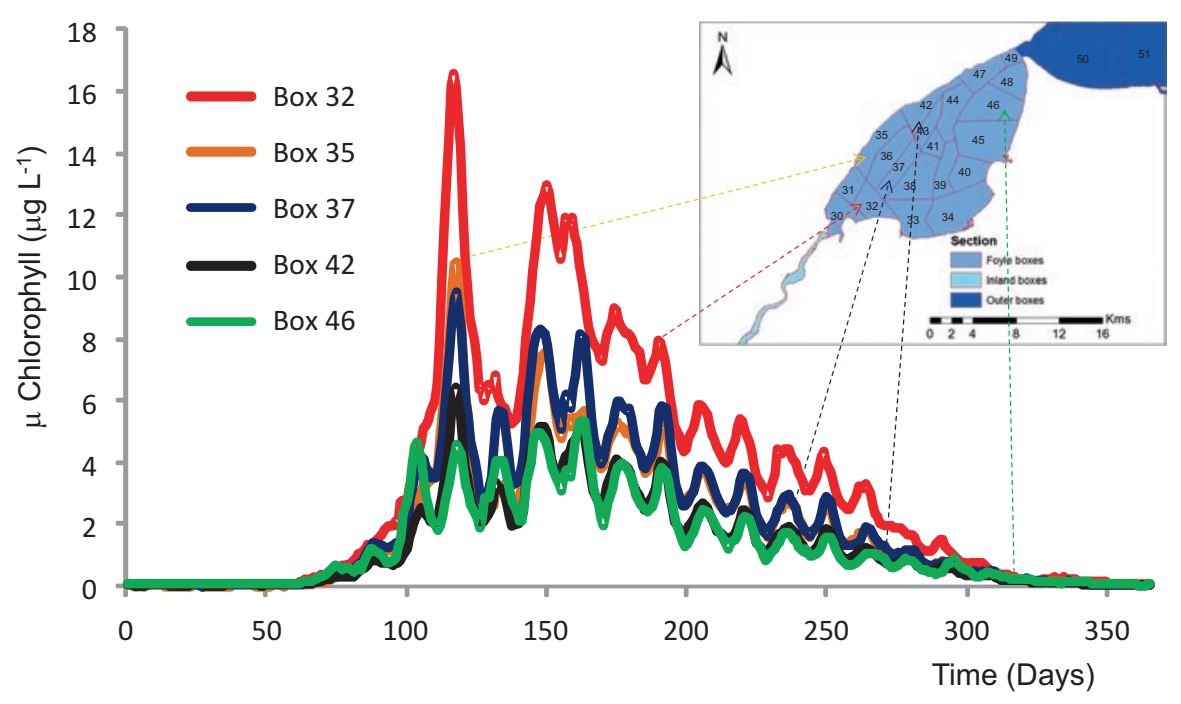

Fig. 27.6 Phytoplankton drawdown in Lough Foyle simulated with the EcoWin.NET systemscale model 
(BQE) such as chlorophyll concentration. The removal of algae (primary symptoms of eutrophication) before the organic decomposition stage (secondary symptoms) also acts to reduce hypoxia, since it greatly lowers the availability of particulate organics, but it should be noted that the role of bivalve filtration in regulating chlorophyll concentration is obviously dependent on various factors, including bivalve stocking density and areal coverage of cultivation, and physical aspects such as flushing time.

This modelling framework was also applied (Fig. 27.7) to analyse various nutrient loading scenarios, and their effect on chlorophyll concentration. The percentile 90 value was chosen as the appropriate indicator, for consistency with the ASSETS model for eutrophication assessment (Bricker et al. 2003), and mean values are shown for all the modelling domain.

The lower line considers the standard nutrient loading and varying stocking densities for bivalves, and the upper line represents the effect of source-control on primary production, without any cultivated bivalves in the system. Under natural conditions (no agricultural activity or urban areas), simulated using the Soil and Water Assessment Tool (SWAT) hydrological model (e.g. Gassman et al. 2007), the chlorophyll $\mathrm{P}_{90}$ is about $6 \mu \mathrm{g} \mathrm{L}^{-1}$, increasing to $9 \mu \mathrm{g} \mathrm{L}^{-1}$ in the present day (without bivalves).

Bivalves, under standard (present-day) nutrient loading conditions, lower the $\mathrm{P}_{90}$ to $4 \mu \mathrm{g} \mathrm{L}^{-1}$, i.e. (in the model) bivalve filter feeders are considerably more successful in mitigating elevated chlorophyll concentrations in Lough Foyle than nitrogen source control.

From a management perspective, it is interesting to analyse the comparative effect of source control and bivalve regulatory services in economic terms. One approach for valuation is shown in Fig. 27.8, which provides cost estimates for both

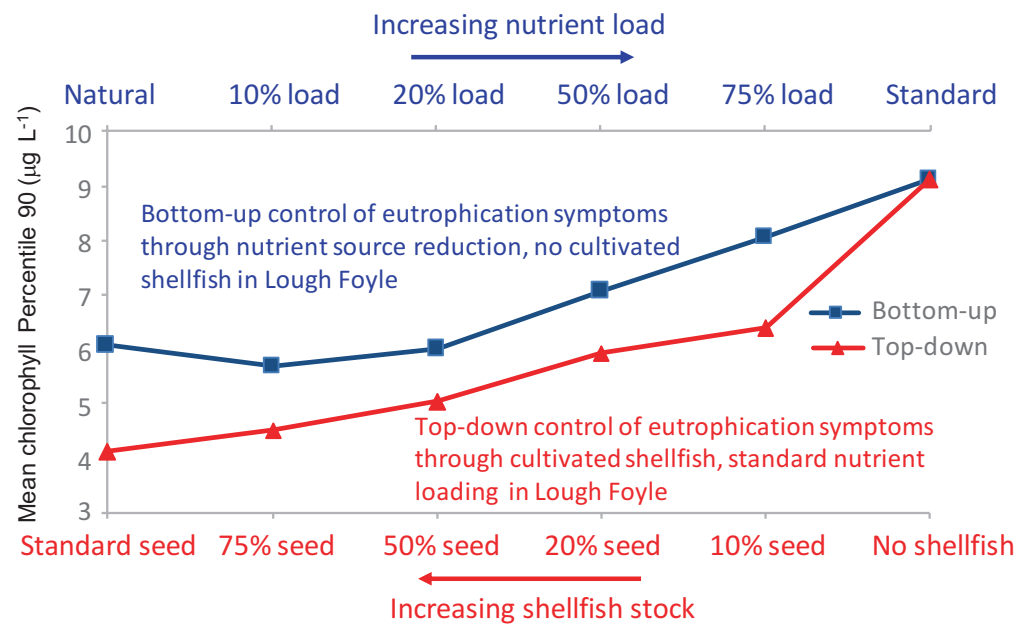

Fig. 27.7 Chlorophyll drawdown with bottom-up and top-down control simulated with the EcoWin.NET system-scale model 


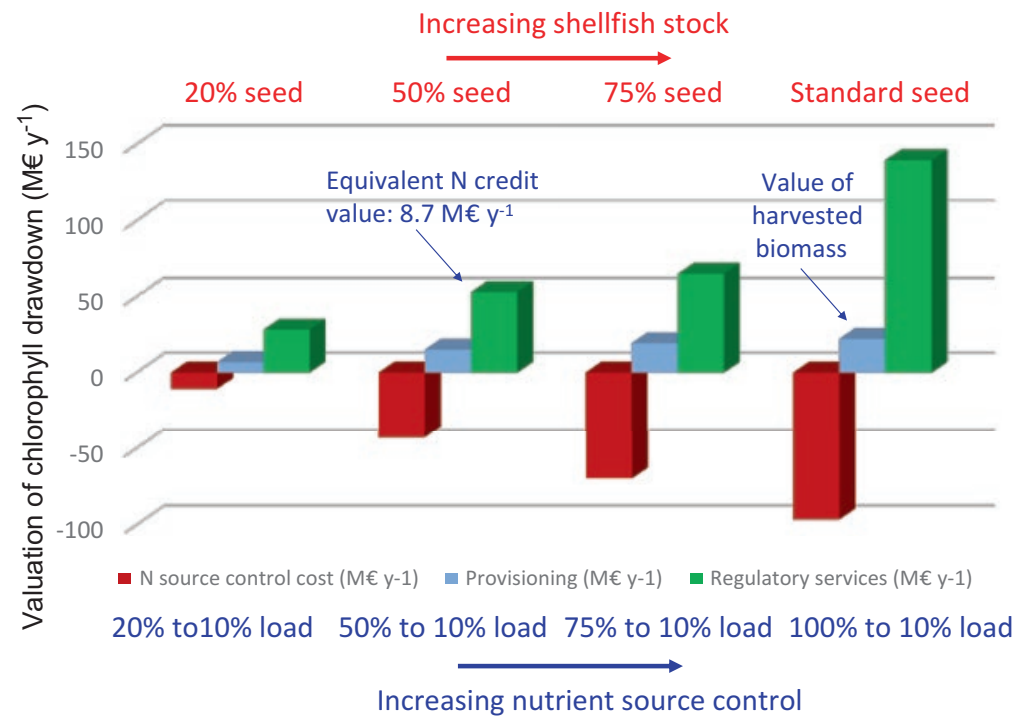

Fig. 27.8 Valuation of bivalve ecosystem services in Lough Foyle calculated using the EcoWin. NET system-scale model; negative values (red bars) are the cost of nutrient source control

types of management measures, i.e. nutrient source control (in red), and bivalve regulatory services (in green). The figure also shows (in blue) the provisioning service from bivalves, i.e. the value of harvested biomass-in the ecosystem model, the biomass of cultivated animals above a user-defined weight threshold is removed from the Lough during the period of harvest, and accrued. The value of the total harvested biomass is then estimated based on the farmgate price of the product.

The calculations are made separately for the two types of measures, but common sense dictates that combined solutions should be the preferred option, not least because of the danger of moral hazard in exempting agriculture from better management practices.

The decrease in $\mathrm{N}$ load, $\Delta \mathrm{L}\left(\mathrm{t}_{\text {year }}{ }^{-1}\right)$, was correlated with the corresponding reduction in chlorophyll $\mathrm{P}_{90}, \Delta \alpha\left(\mu \mathrm{g} \mathrm{L}^{-1}\right)$. The cost of reducing emissions at source was determined by considering a unit cost $10.8 € \mathrm{~kg}^{-1} \mathrm{~N}$, converted from a value of 12.4 USD kg ${ }^{-1} \mathrm{~N}$, estimated by Lindahl et al. (2005) for 47 small stabilization ponds (lagoons) in Sweden, and multiplying by the load reduction $\Delta \mathrm{L}$. Load reduction can thus be expressed in monetary units $\mathrm{C}\left(\mathrm{M} € \mathrm{year}^{-1}\right)$, and regression analysis yields Eq. 27.2, with a correlation coefficient $r=0.999\left(p_{<0.01}\right)$.

$$
C=27.2 \Delta \alpha+3.37
$$

Equation 27.2 states that for Lough Foyle, a reduction of $1 \mu \mathrm{g} \mathrm{L} \mathrm{L}^{-1}$ for chlorophyll $\mathrm{P}_{90}$ costs $30.57 \mathrm{M} €$ year $^{-1}$ in terms of source control. Furthermore, the cost per kg applied is low when compared with data for non-point mitigation (Table 27.5) proposed by Stephenson et al. (2010). Equation 27.2 was used to determine the alterna- 
tive cost of the regulatory service provided by bivalves in Lough Foyle, by calculating the value associated with the chlorophyll $\mathrm{P}_{90}$ decrease for four scenarios, $20 \%, 50 \%, 75 \%$, and $100 \%$ present bivalve stocking density, when compared to no bivalves in the lough. In parallel, equivalent source-control costs are shown for $4 \mathrm{~N}$ loading reduction scenarios, relative to $10 \%$ of the present-day load.

Apart from the systematically higher offset provided by bivalves in each scenario when compared to source control, the most striking observation is the difference in the value of the regulatory service provided by bivalves calculated using the different approaches, i.e. nutrient removal (N), and chlorophyll abatement $(\Delta \alpha)$. The ratio of symptom value (chlorophyll) /causative factor value $(\mathrm{N})$ for the four scenarios varies between 5.8 and 13.7, for the lowest to highest stocking densities $(20 \%, 50 \%$, $75 \%$, and $100 \%$, see Fig. 27.8).

This appears to be the first comparative analysis that focuses on eutrophication indicators, and suggests that for this particular system, the value of regulatory ecosystem services supplied by bivalves-in this case including three different bivalve species-will be underestimated by an order of magnitude if the approach is based on an equivalence of source control.

The degree to which such an approach can be generalised, without development of a complex suite of models for different estuaries and bays, is a question that requires further analysis. In particular, variations in water residence time and underwater light climate will undoubtedly affect the ratio above, since it is well established since the 1950s (Ketchum 1954), that physical conditions strongly constrain phytoplankton bloom development.

Our aim in relating regulation services provided by bivalves to other nutrient management options should be to establish which indicators provide the best metrics for assessment, which methodologies can be used for comparative analysis and valuation, and to develop those outcomes into tools for practical ecosystem management.

\subsection{Conclusions}

Nutrient management in coastal waters requires a holistic approach, and the role of bivalves in nutrient credit trading programmes should form an integral part of ecosystem-based management. This can only be achieved if it is recognized that bivalve farmers should play an active part in market-based control strategies. From the perspective of aquaculture enhancement, which is fundamental for improved food security, this is a triple-win, providing competitiveness of agriculture, ecointensification of aquaculture, and consumer safety.

The food safety issue is particularly relevant because organically extractive aquaculture relies on local environmental conditions, and bivalve filter-feeders can enhance negative aspects, including heavy metals and organic micropollutants, through bioaccumulation and bioamplification. This underscores the need for improved traceability, which is required for any credit trading scheme. An improved understanding of husbandry, and better stock control, brings several other practical 
benefits, including certification, consumer confidence, and access to insurance markets.

From a food security perspective, since the European Union currently imports $71 \%$ of the aquatic products it consumes (European Commission 2016), and the United States imports $86 \%$ (Tiller et al. 2013), any mechanism that can reduce this trade deficit is welcome. The enhancement of bivalve production in European and North American bays and estuaries, where aspects such as xenobiotics are far better regulated than in other parts of the world, will also promote branding (e.g. Made in Europe, Born in the USA), which can drive exports to markets where confidence in internal product safety is weak.

The challenge of sector growth in the West is mainly linked to social licence, which limits spatial expansion. However, if market instruments such as nutrient credit trading expand to accommodate bivalve producers, then existing sites will eco-intensify, boosting yield, improving profitability, and creating jobs.

At present, discussions of valuation such as were presented herein are relevant because they review current knowledge and promote the implementation of integrated management, but from an economic point of view, an ecosystem service is worthless if there is no market for it. It is clear from our analysis of trading mechanisms that the US is by far the most advanced nation in the field of WQT, although HELCOM produced a framework document in 2008 for the Baltic (Green Stream Network 2008), which does not, however, make any reference to bivalves.

In order to promote a European context for involvement of the bivalve aquaculture industry in nutrient credit trading frameworks, it is worth speculating on why the US is considerably more advanced in this area. Potential reasons are: (i) differences in legislation and policy instruments; (ii) concerns that a reduced focus on source control may detract from efforts to reduce land-based nutrient discharge; and (iii) uncertainties about effectiveness as a management tool. While a full discussion of these issues is beyond the scope of this work, we believe that all these aspects need a detailed analysis, if Europe is to move towards integrated nutrient management measures, which insofar as possible internalise the mechanisms used at the basin scale.

Two key differences between the US and Europe can be readily identified: (i) Europe has to deal with enclosed seas such as the Baltic, Black Sea, and the Mediterranean basins, whereas the US marine systems are open; and (ii) as discussed earlier, two of the key EU legal instruments for water policy, the WFD and MSFD, attempted to provide a complete framework for management, but left out aquaculture. Europe is moving toward a much better integration of those instruments with the policies for aquaculture eco-intensification, but there is still some way to go. The US approach of analysing BMPs and enabling approval by regulators of specific aspects such as bivalve grower participation, is a promising approach.

We envisage that nutrient credit trading, and the integration of aquaculture stakeholders, including both finfish producers as emitters and bivalve growers as offset providers, as well as land-based non-point dischargers, will grow substantially over the next decades. More appropriate indicators of ecosystem health will be used, models will play an increasingly important role in assessment and valuation, and communities and coastal management alike will benefit from greater cost internalisation, better traceability, and a closer connection between natural and social systems. 
Acknowledgements The authors wish to thank J.P. Nunes and C.B. Zhu for contributions to the compilation of nutrient loading data, and J. Rose for supplying a water quality dataset for Long Island Sound. We are grateful to K. Stephenson for thoughtful discussion of non-point source nutrient trading issues, and to T. O'Higgins for re-working the modelling framework shown in Fig. 27.5. We would also like to thank the EASE project team (listed in Ferreira et al. 2016) for the work executed for Lough Foyle. Finally, we are grateful to three reviewers whose comments substantially improved an earlier draft of this work.

\section{References}

Acharya D (2011) Fillet quality and yield of farmed Atlantic salmon (Salmo salar L.): variation between families, gender differences and the importance of maturation. M.Sc. Thesis, Norwegian University of Life Sciences, 64 pp. https://brage.bibsys.no/

Ærtebjerg G, Carstensen J, Dahl K, Hansen J, Nygaard K, Rygg B, Sørensen K, Severinsen G, Casartelli S, Schrimpf W, Schiller C, Druon JN, (2001) Eutrophication in Europe's coastal waters. European Environment Agency, Topic report 7/2001, 86 pp. http://www.eea.europa.eu/

Andersen JH, Schlüter L, Ærtebjerg G (2006) Coastal eutrophication: recent developments in definitions and implications for monitoring strategies. J Plankton Res 28(7):621-628

Anonymous (1991a) Council Directive of 21 May 1991 concerning urban waste water treatment (91/271/EEC). Off J L135

Anonymous (1991b) Council Directive 91/676/EEC of 12 December 1991 concerning the protection of waters against pollution caused by nitrates from agricultural sources. Off J L375

Borja A, Bricker SB, Dauer DM, Demetriades NT, Ferreira JG, Forbes AT, Hutchings P, Jia X, Kenchington R, Marques JC, Zhu CB (2008) Overview of integrative tools and methods in assessing ecological integrity in estuarine and coastal systems worldwide. Mar Pollut Bull 56:1519-1537

Boynton WR, Kemp WM, Keefe CW (1982) A comparative analysis of nutrients and other factors influencing estuarine phytoplankton production. In: Kennedy VS (ed) Estuarine comparisons. Academic, New York, pp 69-90

Bricker SB, Ferreira JG, Simas T (2003) An integrated methodology for assessment of estuarine trophic status. Ecol Model 169(1):39-60

Bricker SB, Longstaff B, Dennison W, Jones A, Boicourt K, Wicks C, Woerner J (2007) Effects of nutrient enrichment in the Nation's estuaries: a decade of change, National estuarine eutrophication assessment update. NOAA Coastal Ocean Program Decision Analysis Series No. 26. National Centers for Coastal Ocean Science, Silver Spring, MD. 322 pp

Bricker SB, Longstaff B, Dennison W, Jones A, Boicourt K, Wicks C, Woerner J (2008) Effects of nutrient enrichment in the nation's estuaries: a decade of change. Special issue of Harmful Algae 8:21-32

Branosky E, Jones C, Selman M (2011) Compareison tables of state nutrient trading programs in the Chesapeake Bay watershed. Fact sheet. World Resources Institute, Washington, DC

China Fishery Statistical Yearbook (2016) Bureau of Fisheries, Ministry of Agriculture of the People's Republic of China, 2016. China Agricultural Press, Beijing. ISBN: 978-7-109-21691-4

Cloern JE (1982) Does the benthos control phytoplankton biomass in South San Francisco Bay? Mar Ecol Prog Ser 9:191-202

Cloern J (2001) Our evolving conceptual model of the coastal eutrophication problem. Mar Ecol Prog Ser 210:223-253

Collins AL, McGonigle DF (2008) Monitoring and modelling diffuse pollution from agriculture for policy support: UK and European experience. Environ Sci Pol 11(2):97-101 
Connecticut Department of Environmental Protection (CT DEP) (2010) An incentive-based water quality trading program. The Connecticut Department of Environmental Protection. Bureau of Water Protection and Land Reuse, Hartford, 10pp

Dales JH (1968) Pollution, property \& prices: an essay in policy-making and economics. University of Toronto Press, Toronto, pp VII-111S

DeBoe G, Stephenson K (2016) Transactions costs of expanding nutrient trading to agricultural working lands: a Virginia case study. Ecol Econ 130:176-185

Diaz RJ, Rosenberg R (2008) Spreading dead zones and consequences for marine ecosystems. Science 321:926-929

European Commission (2016) Facts and figures on the common fisheries policy. European Commission, $56 \mathrm{pp}$

FAO (Food and Agriculture Organization of the United Nations) (2016) The state of world fisheries and aquaculture (SOFIA). FAO, Rome, $204 \mathrm{pp}$

Ferreira JG, Nobre AM, Simas TC, Silva MC, Newton A, Bricker SB, Wolff WJ, Stacey PE, Sequeira A (2006) A methodology for defining homogeneous water bodies in estuaries - application to the transitional systems of the EU Water Framework Directive. Estuar Coast Shelf Sci 66(3/4):468-482

Ferreira JG, Hawkins AJS, Bricker SB (2007a) Management of productivity, environmental effects and profitability of bivalve aquaculture - the Farm Aqua-culture Resource Management (FARM) model. Aquaculture 264:160-174

Ferreira JG, Bricker SB, Simas TC (2007b) Application and sensitivity testing of an eutrophication assessment method on coastal systems in the United States and European Union. J Environ Manag 82:433-445

Ferreira JG, Hawkins AJS, Monteiro P, Moore H, M. Service, Pascoe PL, Ramos L, Sequeira A (2008) Integrated assessment of ecosystem-scale carrying capacity in shellfish growing areas. Aquaculture 275:138-151

Ferreira JG, Andersen JH, Borja A, Bricker SB, Camp J, Cardoso da Silva M, Garcés E, Heiskanen A-S, Christoph H, Ignatiades L, Lancelot C, Menesguen A, Tett P, Hoepffner N, Claussen U (2011) Indicators of human-induced eutrophication to assess the environmental status within the European Marine Strategy Framework Directive. Estuar Coast Shelf Sci 93:117-131

Ferreira JG, Bricker SB (2015) Nitrogen remediation through shellfish aquaculture - a model analysis. AE2015, Rotterdam, European Aquaculture Society, http://www.ecowin.org/eas2015

Ferreira JG, Bricker SB (2016) Goods and services of extensive aquaculture: shellfish culture and nutrient trading. Aquac Int 24(3):803-825

Ferreira JG, Moore H, Boylan P, Jordan C, Lencart-Silva JD, McGonigle C, McLean S, Nunes JP, Service M, Zhu CB (2016) Application of a multi-model framework for integrated ecosystem management in Lough Foyle. In: EAAP 2016, 67th annual meeting of the European Federation of Animal Science, Belfast, UK, 29/8-2/9 2016

Gassman PW, Reyes MR, Green CH, Arnold JG (2007) The soil and water assessment tool: historical development, applications, and future research directions. Am Soc Agric Biol Eng 50(4):1211-1250

Gerritsen J, Holland AF, Irvine DE (1994) Suspension-feeding bivalves and the fate of primary production: an estuarine model applied to Chesapeake Bay. Estuaries 17(2):403-416

Green Stream Network (2008) Framework for a nutrient quota and credits trading system for the contracting parties of HELCOM in order to reduce eutrophication of the Baltic. Final report to the Nordic Environment Finance Organization. Green Stream Network, Helsinki

Gren IM, Jonzon Y, Lindqvist M (2008) Cost of nutrient reductions to the Baltic Sea - technical report. SLU, Institutionen för ekonomi 2008:1, 65 pp

Gunningham N, Sinclair D (2005) Policy instrument choice and diffuse source pollution. J Environ Law 17(1):51-81

HELCOM (2009) Andersen JH, Laamanen M (eds) Eutrophication in the Baltic Sea - an integrated thematic assessment of the effects of nutrient enrichment and eutrophication in the Baltic Sea region.Baltic Sea Environment Proceedings No. 115B. 148pp

HELCOM (2010) Ecosystem health of the Baltic Sea 2003-2007: HELCOM initial holistic assessment.Baltic Sea Environment Proceedings No. 122 
HELCOM (2014) Eutrophication status of the Baltic Sea 2007-2011 - a concise thematic assessment. Baltic Sea Environment Proceedings No. 143.

Higgins CB, Stephenson K, Brown BL (2011) Nutrient bioassimilation capacity of aquacultured oysters: quantification of an ecosystem service. J Environ Qual 40(1):271-277

Houle J, Roseen R, Ballestero T, Puls T, Sherrard J (2013) A comparison of maintenance cost, labor demands, and system performance for LID and conventional stormwater management. J Environ Eng 139:932-938

Howarth RW (1988) Nutrient limitation of net primary production in marine ecosystems. Ann Rev Ecol 19:89-110

Howarth RW, Sharpley A, Walker D (2002) Sources of nutrient pollution to coastal waters in the United States: implications for achieving coastal water quality goals. Estuaries 25(4b):656-676

Jones C, Branosky E, Selman M, Perez M (2010) How nutrient trading could help restore the Chesapeake Bay. World Resources Institute, Washington, DC. http://wwwwriorg/publication/ how-nutrienttrading-could-help-restore-chesapeake-bay Accessed 12 Feb 2017

Kellogg ML, Cornwell JC, Owens MS, Paynter KT (2013) Denitrification and nutrient assimilation on a restored oyster reef. Mar Ecol Prog Ser 480:1-19

Kellogg ML, Smyth AR, Luckenbach MW, Carmichael RH, Brown BL, Cornwell JC, Piehler MF, Owens MS, Dalrymple DJ, Higgins CB (2014) Use of oysters to mitigate eutrophication in coastal waters. Estuar Coast Shelf Sci 151:156-168

Ketchum BH (1954) Relation between circulation and planktonic populations in estuaries. Ecology 35:191-200

Lancelot C, Thieu V, Polard A, Garnier J, Billen G, Hecq W, Gypens N (2011) Cost assessment and ecological effectiveness of nutrient reduction options for mitigating Phaeocystis colony blooms in the Southern North Sea: an integrated modeling approach. Sci Total Environ 409(11):2179-2191

Lal H (2010) Nutrient credit trading- a market-based approach for improving water quality. In: Delgado JA, Follett RF (eds) Advances in nitrogen management for water quality. Soil and Water Conservation Society, Ankeny, pp 344-361

Lindahl O, Hart R, Hernroth B, Kollberg S, Loo L, Olrog L, Rehnstam-Holm A (2005) Improving marine water quality by mussel farming: a profitable solution for Swedish Society. Ambio 34(2):131-138

Mann R, Ryther JH (1977) Growth of six species of bivalve molluscs in a waste recyclingaquaculture system. Aquaculture 11:231-245

National Research Council (NRC) (1993) Managing wastewater in coastal urban areas. National Academy Press, Washington, DC

National Research Council (NRC) (2000) Clean coastal waters: understanding and reducing the effects of nutrient pollution. National Academy Press, Washington, DC

Nixon SW, Pilson MEQ (1983) In: Carpenter EJ, Capone DG (eds) Nitrogen in the marine environment. Academic Press, New York, pp 565-648

Nixon SW (1995) Coastal marine eutrophication: a definition, social causes, and future concerns. Ophelia 41:199-219

Nobre AM, Ferreira JG, Nunes JP, Yan X, Bricker S, Corner R, Groom S, Gu H, Hawkins A, Hutson R, Lan D, Lencart e Silva JD, Pascoe P, Telfer T, Zhang X, Zhu M (2010) Assessment of coastal management options by means of multilayered ecosystem models. Estuar Coast Shelf Sci 87:43-62

Nunes JP, Ferreira JG (2016) Comparing agricultural and urban nutrient loads to coastal systems. EAAP 2016, 67th annual meeting of the European Federation of Animal Science, Belfast, UK, 29/8-2/9 2016

Nunneri C, Windhorst W, Kerry Turner R, Hermann Lenhart H (2007) Nutrient emission reduction scenarios in the North Sea: an abatement cost and ecosystem integrity analysis. Ecol Indic 7(4):776-792

Officer CB, Smayda TJ, Mann R (1982) Benthic filter feeding: a natural eutrophication control. Mar Ecol Prog Ser 9:191-202 
Osmond D, Meals D, Hoag D, Arabi M, Luloff A, Jennings G, Mcfarland M, Spooner J, Sharpley A, Line D (2012) Improving conservation practices programming to protect water quality in agricultural watersheds: lessons learned from the National Institute of Food and Agricultureconservation effects assessment project. J Soil Water Conserv 67(5):122A-127A. https://doi. org/10.2489/jswc.67.5.122A

OSPAR (2010) Moffat C, Emmerson R, Weiss A, Symon C, Dicks L (eds) Quality status report 2010. OSPAR Commission, London. 176pp

Oyster BMP Expert Panel (2016) Panel recommendations on the Oyster BMP nutrient and suspended sediment reduction effectiveness determination decision framework and nitrogen and phosphorus assimilation in oyster tissue reduction effectiveness for oyster aquaculture practices. Report submitted to the Chesapeake Bay partnership water quality goal implementation team, September 22, 2016. www.chesapeakebay.net/calendar/event/24330/.

Petersen JK, Hasler B, Timmermann K, Nielsen P, Tørring DB, Larsen MM, Holmer M (2014) Mussels as a tool for mitigation of nutrients in the marine environment. Mar Pollut Bull 82:137-143

Rabalais N, Turner RE, Wiseman WJ Jr (2002) Gulf of Mexico Hypoxia, A.K.A. "The Dead Zone". Annu Rev Ecol Syst 33:235-263

Rose JM, Bricker SB, Ferreira JG (2015) Comparative analysis of modeled nitrogen removal by shellfish farms. Mar Pollut Bull 91(1):185-190

Reitsma J, Murphy DC, Archer AF, York RH (2016) Nitrogen extraction potential of wild and cultured bivalves harvested from nearshore waters of Cape Cod, USA. https://doi.org/10.1016/j. marpolbul.2016.12.072

Ribaudo MO, Gottlieb J (2011) Point-nonpoint trading-can it work? J Am Water Resour Assoc 47(1):5-14

Rice E, Stewart G (2013) Analysis of interdecadal trends in chlorophyll and temperature in the Central Basin of Long Island Sound. Estuar Coast Shelf Sci 128:64-75

Rose JM, Bricker SB, Tedesco MA, Wikfors GH (2014) A role for shellfish aquaculture in coastal nitrogen management environ. Sci Technol 2014(48):2519-2525. https://doi.org/10.1021/ es4041336

Ryther JH, Dunstan WM (1971) Nitrogen, phosphorus, and eutrophication in the coastal marine environment. Science 171:1008-1013

Saurel C, Ferreira JG, Cheney D, Suhrbier A, Dewey B, Davis J, Cordell J (2014) Ecosystem goods and services from Manila clam culture in Puget Sound: a modelling analysis. Aquac Environ Interact 5:255-270

Shortle J (2013) Economics and environmental markets: lessons from water-quality trading. Agric Resour Econ Rev 42(1):57-74

STAC (Chesapeake Bay Program Scientific and Technical Advisory Committee) (2013) Evaluation of the use of shellfish as a method of nutrient reduction in the Chesapeake Bay. STAC Publ. \#13-005, Edgewater. 65 pp

State Oceanic Administration (SOA) of China (2016) Bulletin of Marine Environmental Status of China for the year of 2015. SOA, 2016. http://www.coi.gov.cn/gongbao/nrhuanjing/nr2015/

Stephenson K, Aultman S, Metcalfe T, Miller A (2010) An evaluation of nutrient nonpoint offset trading in Virginia: a role for agricultural nonpoint sources? Water Resour Res 46:W04519

Stephenson K, Shabman L (2017a) Nutrient Assimilation Services for water quality credit trading programs: a comparative analysis with nonpoint source credits. Coast Manag 45(1):1-20. https://doi.org/10.1080/08920753.2017.1237240

Stephenson K, Shabman L (2017b) Where did the agricultural nonpoint source trades go? Lessons from Virginia water quality trading programs. J Am Water Resour Assoc 53(5):1178-1194

Tiller R, Gentry R, Richards R (2013) Stakeholder driven future scenarios as an element of interdisciplinary management tools; the case of future offshore aquaculture development and the potential effects on fishermen in Santa Barbara, California. Ocean Coast Manag 73:127-135

Town of Mashpee Sewer Commission (2015) Final recommended plan/final environmental impact report. Comprehensive wastewater management plan, Town of Mashpee. Prepared by GHD, Inc., Hyannis, Massachusetts. 349 pp 
Tong Y, Zhao Y, Zhen G, Chi J, Liu X, Lu Y, Wang X, Yao R, Chen J, Zhang W (2015) Nutrient loads flowing into coastal waters from the main rivers of China (2006-2012). Sci Rep 5:16678. https://doi.org/10.1038/srep16678

United States Environmental Protection Agency (USEPA) (2004a) Primer for municipal wastewater treatment systems. EPA 832-R-04-001, U.S. Environmental Protection Agency. Office of Water, Washington, DC, $30 \mathrm{pp}$

United States Environmental Protection Agency (USEPA) (2004b) Water quality trading assessment handbook: can water quality trading advance your watershed's goals? EPA 841-B-04001. Office of Water, Washington, DC

United States Environmental Protection Agency (USEPA) (2008a) Handbook for developing watershed plans to restore and protect our waters. EPA 841-B-08-002, U.S. Environmental Protection Agency. Office of Water, Washington, DC, 400 pp

United States Environmental Protection Agency (USEPA) (2008b) EPA's 2008 Report on the Environment. National Center for Environmental Assessment, Washington, DC; EPA/600/R-07/045F. http://www.epa.gov/roe, http://cfpub.epa.gov/ncea/cfm/recordisplay. cfm?deid $1 / 4190806$

United States Environmental Protection Agency (USEPA) (2017) Implementing Clean Water Act Section 303(d): impaired waters and Total Maximum Daily Loads (TMDLs). https://www.epa. gov/tmdl. Accessed 9 Feb 2017

Virginia DEQ (Department of Environmental Quality) (2008) Trading nutrient reductions from nonpoint source best management practices in the Chesapeake Bay Watershed: Guidance for Agricultural Landowners and Your Potential Trading Partners. http://www.deq.virginia.gov/ Portals/0/DEQ/Water/PollutionDischargeElimination/VANPSTradingManual_2-5-08.pdf. $40 \mathrm{pp}$

Xiao Y, Ferreira JG, Bricker SB, Nunes JP, Zhu M, Zhang X (2007) Trophic assessment in Chinese coastal systems - review of methods and application to the Changjiang (Yangtze) Estuary and Jiaozhou Bay. Estuaries \& Coasts 30(6):901-918

Wang X, Andresen K, Handå A, Jensen B, Reitan KI, Olsen Y (2013) Chemical composition and release rate of waste discharge from an Atlantic salmon farm with an evaluation of IMTA feasibility. Aquacult Environ Interact 4:147-162

Wang X, Broch OB, Forbord S, Handå A, Skjermo J, Reitan KI, Vadstein O, Olsen Y (2014) Assimilation of inorganic nutrients from salmon (Salmo salar) farming by the macroalgae (Saccharina latissima) in an exposed coastal environment: implications for integrated multitrophic aquaculture. J Appl Phycol 26:1869-1878

Wise DR, Johnson HM (2011) Surface-water nutrient conditions and sources in the United States Pacific Northwest. J Am Water Resour Assoc 47(5):1110-1135 https://www.ncbi.nlm.nih.gov/ pmc/articles/PMC3307616/

Zaldivar JM, Cardoso AC, Viaroli P, Newton A, de Wit R, Ibanez C, Reizopoulou S, Somma F, Razinkovas A, Basset A, Holmer M, Murray N (2008) Eutrophication in transitional waters: an overview. Transitional Waters Monogr 1:1-78

Open Access This chapter is licensed under the terms of the Creative Commons Attribution 4.0 International License (http://creativecommons.org/licenses/by/4.0/), which permits use, sharing, adaptation, distribution and reproduction in any medium or format, as long as you give appropriate credit to the original author(s) and the source, provide a link to the Creative Commons license and indicate if changes were made.

The images or other third party material in this chapter are included in the chapter's Creative Commons license, unless indicated otherwise in a credit line to the material. If material is not included in the chapter's Creative Commons license and your intended use is not permitted by statutory regulation or exceeds the permitted use, you will need to obtain permission directly from the copyright holder.

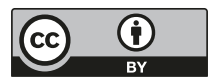

